\title{
Having a child before becoming an adult: Exploring the economic impact in a multi-country analysis
}

Women Deliver

Population Council

Follow this and additional works at: https://knowledgecommons.popcouncil.org/departments_sbsr-rh How does access to this work benefit you? Let us know!

\section{Recommended Citation}

Women Deliver and Population Council. 2019. "Having a child before becoming an adult: Exploring the economic impact in a multi-country analysis," report prepared for the Women Deliver 2019 Conference. New York: Women Deliver. 


\section{HAVING A CHILD BEFORE BECOMING AN ADULT}

Exploring the Economic Impact in a Multi-Country Analysis

Prepared by:

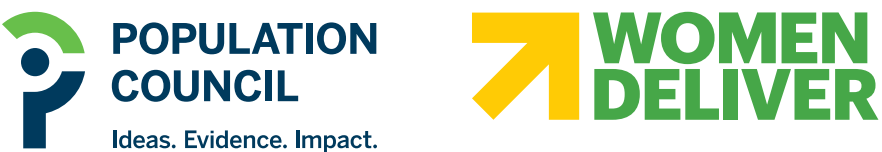




\section{Suggested Citation:}

Women Deliver and The Population Council. Having a Child Before Becoming an Adult: Exploring the Economic Impact in a Multi-Country Analysis. New York: Women Deliver, 2019.

\section{Acknowledgements:}

- The Population Council team who contributed to this report included: Michelle Hindin, Stephanie Psaki, Leah Jarvis, Christina Misunas, Talia Rueschemeyer-Bailey, and Ann Blanc.

- The Women Deliver team who contributed to this report included: Katja Iversen, Susan Papp, Divya Mathew, Rachel Fowler, Allison Wittry, and Kelsey Cioffi.

- Dr. Veloshnee Govender, scientist at the Department of Reproductive Health and Research, World Health Organization served as a reviewer for this study.

- This research was possible thanks to the contributions by the New Venture Fund and the Swiss Agency for Development and Cooperation.

\section{PHOTO CREDITS:}

Cover photo by Brian Otieno

Pages 5, 7, 32, and 39 photos courtesy of Population Council

Page 9 photo by Artem Beliaikin on Unsplash

Pages 15 and 37 photos by Mark Tuschman

Page 23 photo by Paolo Nicolello on Unsplash

Page 29 photo by Nandhu Kumar on Unsplash

Page 35 photo by Jeison Higuita on Unsplash

Page 43 photo by Annie Spratt on Unsplash 
PART I. INTRODUCTION

25 Years in the Making: Progress in Women's Sexual and Reproductive Health 10

Measuring and Assessing Women's Economic Empowerment 11

The Relationship between Sexual and Reproductive Health and Economic Empowerment 12

PART II. METHODOLOGY

Data Sources and Indicators 16

$\begin{array}{ll}\text { Data Analysis } & 17\end{array}$

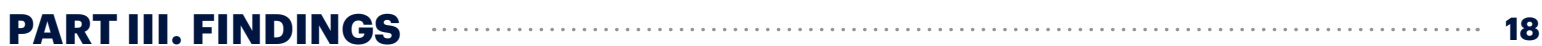

Adolescent Childbearing Around the World 19

Women's Employment and Earnings Around the World 21

$\begin{array}{lr}\text { Women's Employment } & 21\end{array}$

$\begin{array}{ll}\text { Type of Earnings } & 23\end{array}$

Relationship between Adolescent Childbearing and Economic Empowerment 25

Adolescent Childbearing and Women's Employment 25

$\begin{array}{ll}\text { Adolescent Childbearing and Cash Earnings } & 26\end{array}$

PART IV. COUNTRY SNAPSHOTS

Country Snapshot 1: Adolescent Girls Empowerment Program, Zambia 28

Country Snapshot 2: Adolescent Childbearing and Economic Outcomes in Bihar, India 29

PART V. CONTROL OVER EARNINGS: DESCRIPTIVE ANALYSIS $\ldots \ldots \ldots \ldots \ldots . . .31$

PART VI. STUDY LIMITATIONS

PART VII. CONCLUSIONS

PART VIII. RECOMMENDATIONS

$\begin{array}{ll}\text { Next Steps for Research } & 44\end{array}$

$\begin{array}{ll}\text { References } & 45\end{array}$

$\begin{array}{ll}\text { Annex } & 50\end{array}$ 
BOXES, FIGURES, MAPS, AND TABLES

Box 1. Defining Sexual and Reproductive Health 10

Box 2. Defining Women's Economic Empowerment

Map 1. The Prevalence of Adolescent Childbearing Among Women Ages 20 to 24

Figure 1. Percent of Women Who had a Child by Age 18, by Country and Age Group

Figure 2. Percent of Women Ages 20 to 49 Who Were Employed in the Past Year

Figure 3. Percent Distribution of Women Ages 20 to 49 Who Worked in the Past Year, by Type of Earnings 24

Figure 4. Odds of Being Employed in the Past 12 Months After Having a Child by Age 18, by Age Group

Figure 5. Odds of Earning Cash After Having a Child by Age 18 Among Women Employed in the Past 12 Months, by Age Group

Figure 6. Percent of Women Ages 23 to 27 Who Reported Working in Exchange for Payment, by Whether They Gave Birth by Age 18

Figure 7. Percent of Currently Married/Cohabitating Women Ages 20 to 24 Who Were Employed, Earning Cash, and Controlling Their Cash Earnings

Table 1. Surveys Included in the Analysis by Regional Groupings

Table 2. Percent of Women Employed in the Past 12 Months, by Age Group and Region

Table 3. Percent of Women Ages 20 to 49 Who Are Currently Married or Living in Union, by Country 
DHS: Demographic and Health Surveys

DRC: Democratic Republic of the Congo

ICPD: International Conference on Population and Development

SRH: sexual and reproductive health

SRHR: sexual and reproductive health and rights

UHC: universal health coverage 


\section{When a woman has a child before the age of 18 , what does her economic future look like?}

This report, prepared by Population Council and Women Deliver, presents findings from one of the first multi-country analyses to examine the short- and long-term impacts of having a child before age 18 on employment and monetary compensation (cash earnings). Cash earnings (as opposed to in-kind payments and unpaid work) play an important role in economic empowerment. Research suggests women receiving cash are more likely to be able to make decisions about their own healthcare and education. The study dives further into women's economic empowerment by analyzing married women's sole control over her cash earnings. A woman's power to make her own decisions over her health, income, and life choices is a marker of empowerment and a core element of gender equality.

Women's sexual and reproductive health and rights are inextricably linked to their economic empowerment. Both factors play essential roles in achieving a more gender-equitable world and reaching development goals. Fully meeting contraceptive needs in developing countries and providing comprehensive care for all pregnant women and newborns would reduce unintended pregnancies, unplanned births, and induced abortions, leading to an estimated $\mathbf{7 3}$ percent decrease in maternal deaths and $\mathbf{8 0}$ percent in newborn deaths. ${ }^{\mathbf{5}}$ Fully closing the gender gap in workplaces could add up to US\$28 trillion in annual gross domestic product by 2025 . $^{6}$ It has been estimated that every $\$ 1$ invested in meeting the unmet need for contraceptives yields as much as $\$ 60$ to $\$ 100$ in long-term beneffits from economic growth. ${ }^{\mathbf{7}}$ Despite these benefits, the world is far from meeting the sexual and reproductive needs of girls and women and from closing the economic gender gap.

\section{This study explores the association between having a child before 18 and economic opportunity.}

The findings have implications on both the Individual Power (girls' and women's individual power, self-esteem, and agency) and Structural Power (the systems, barriers, and opportunities for progress in power relations, including political, economic, and social structures).

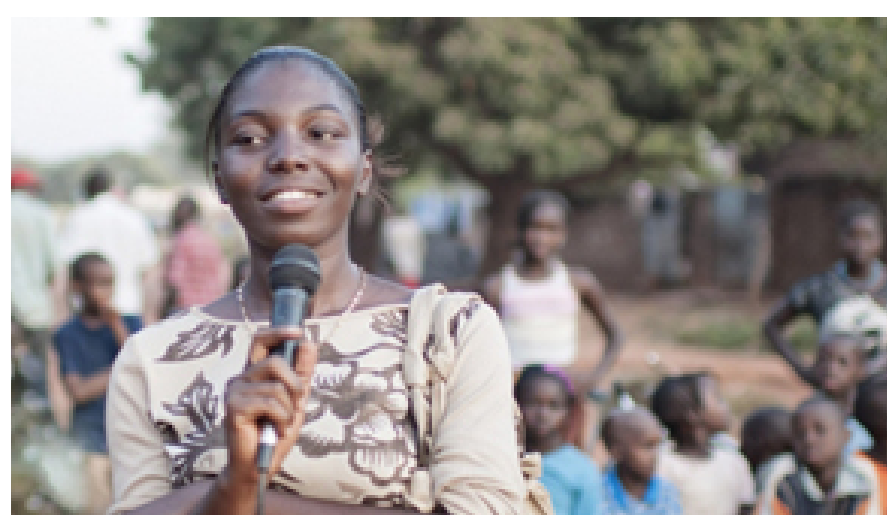


An analysis of data representing more than 600 million women, ages 20 to 49, from 43 low- and middleincome countries ${ }^{8}$ found that:

\section{There is a strong and consistent lifelong negative association between having a child during adolescence and a woman's economic empowerment.}

Women, ages 20 to 24, who had an adolescent birth are 1.2 times more likely to work than their peers.

Young mothers may be pushed into working by economic necessity.

This effect of adolescent childbearing on employment disappears among women ages 25 to 49.
Women who have a child before the age of 18 are set back economically throughout their lives. Across all age groups, working women who had a child during adolescence are less likely to earn cash for their work than women who did not have a child during adolescence.

Most women, ages 20 to 49, are employed (regardless of having a child before 18); however, the work is often not economically empowering.

More than half of all women in more than three quarters of the countries analyzed were employed. Employment tends to be lowest among women ages 20 to 24 years old and increases steadily with age. In some countries, employment levels off after age 40.
The percentage of women paid in cash for their work varies widely across countries. The percentage of working women paid in cash ranges from less than 30 percent in Burundi and Rwanda to more than 90 percent in Colombia, Guatemala, the Maldives, and South Africa.

Unpaid work outside of the household is the second most common form of employment in $\mathbf{2 2}$ of $\mathbf{4 3}$ countries after working for cash, and the most common form of employment in five countries. Overall, unpaid work outside the household accounts for at least 10 percent of women's employment in more than half of the countries analyzed.

\section{Married or cohabiting women's control over cash earnings generally remains low.}

Less than $\mathbf{5 0}$ percent of married or cohabiting women work, earn cash, and have control over their earnings across all countries studied, except Cambodia and Togo. 


\section{CONCLUSIONS}

Taken together these results demonstrate that when a woman has a child before the age of $\mathbf{1 8}$, her economic and financial options become more limited throughout her lifetime.

The evidence paints a picture of the difficult and important decisions young mothers may face. Young mothers may be compelled to work out of necessity in jobs that may not promote their economic empowerment-a reality that can extend throughout the rest of their reproductive lives.

\section{RECOMMENDATIONS}

What governments, policymakers, civil society, and donors can do:

\section{Improve}

the provision of, and access to, high-quality, youth-friendly sexual and reproductive health services and information before, during, and after girls and women have begun having children.

\section{Commit}

to collect nationally representative gender- and age-disaggregated data and to use evidence to inform policies and practices.

\section{Develop}

policies and programs to open-up a range of employment opportunities that are economically empowering for girls and women. These include policies that are compatible with motherhood, such as social protection systems (for example, parental leave policies, old-age pensions, flexible working hours, child allowances) and recognize and value unpaid care work.

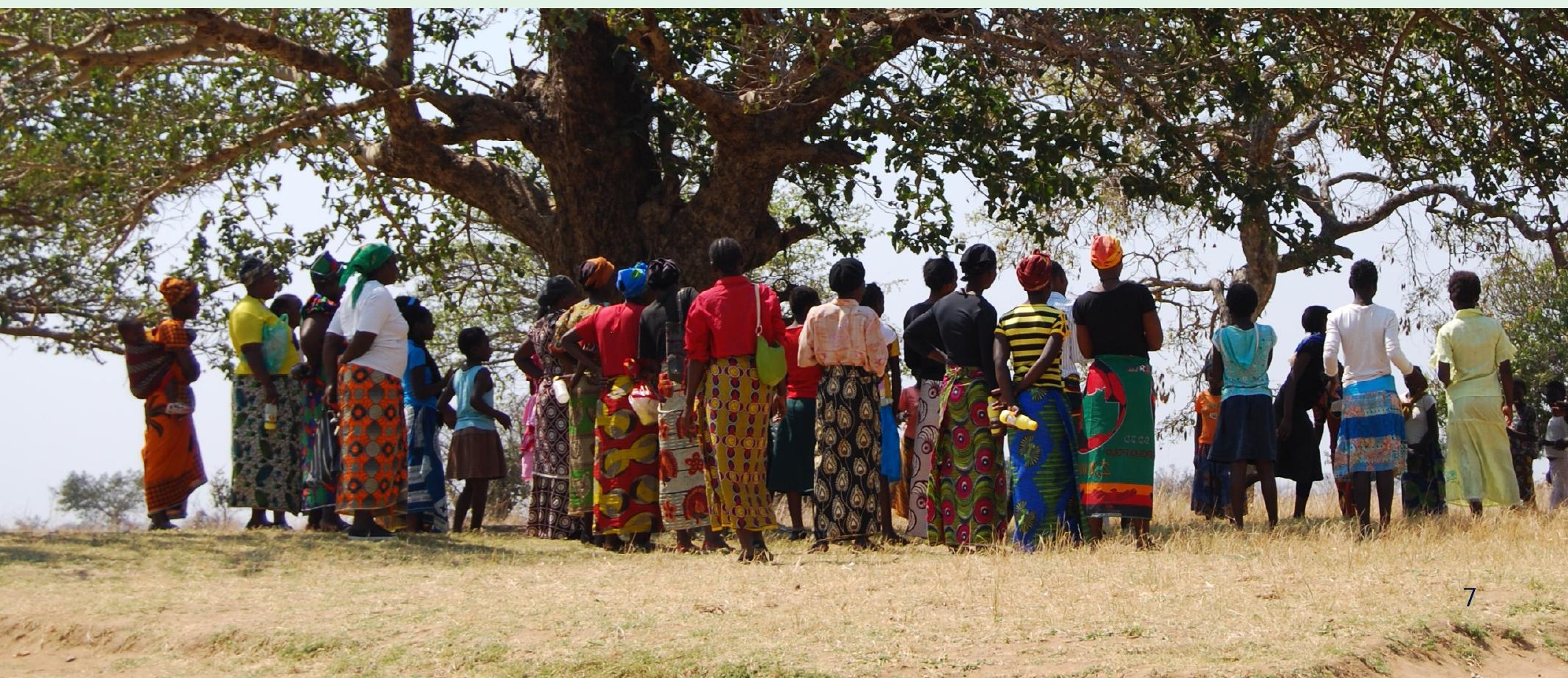


PART I.

Introduction 


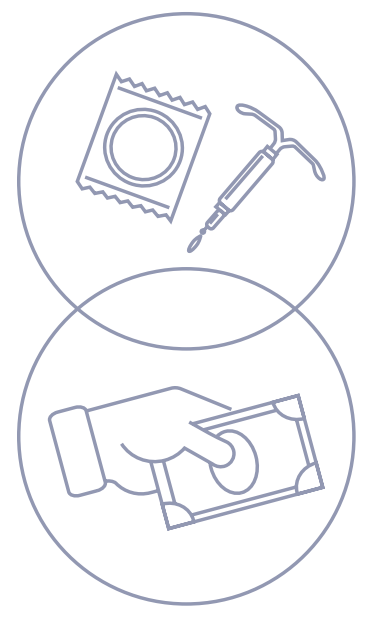

\section{A woman's sexual and reproductive health and her economic empowerment are inextricably linked.}

Both factors play essential roles in increasing a woman's agency and achieving a more gender equitable world. More specifically, the health of girls and women-especially their sexual and reproductive health (SRH)is linked to individual well-being, gender equality, and inclusive and sustainable growth. ${ }^{9}$ It has been estimated that for every $\$ 1$ invested in meeting the unmet need for contraceptives yields as much as $\$ 60$ to $\$ 100$ in long-term benefits from economic growth?

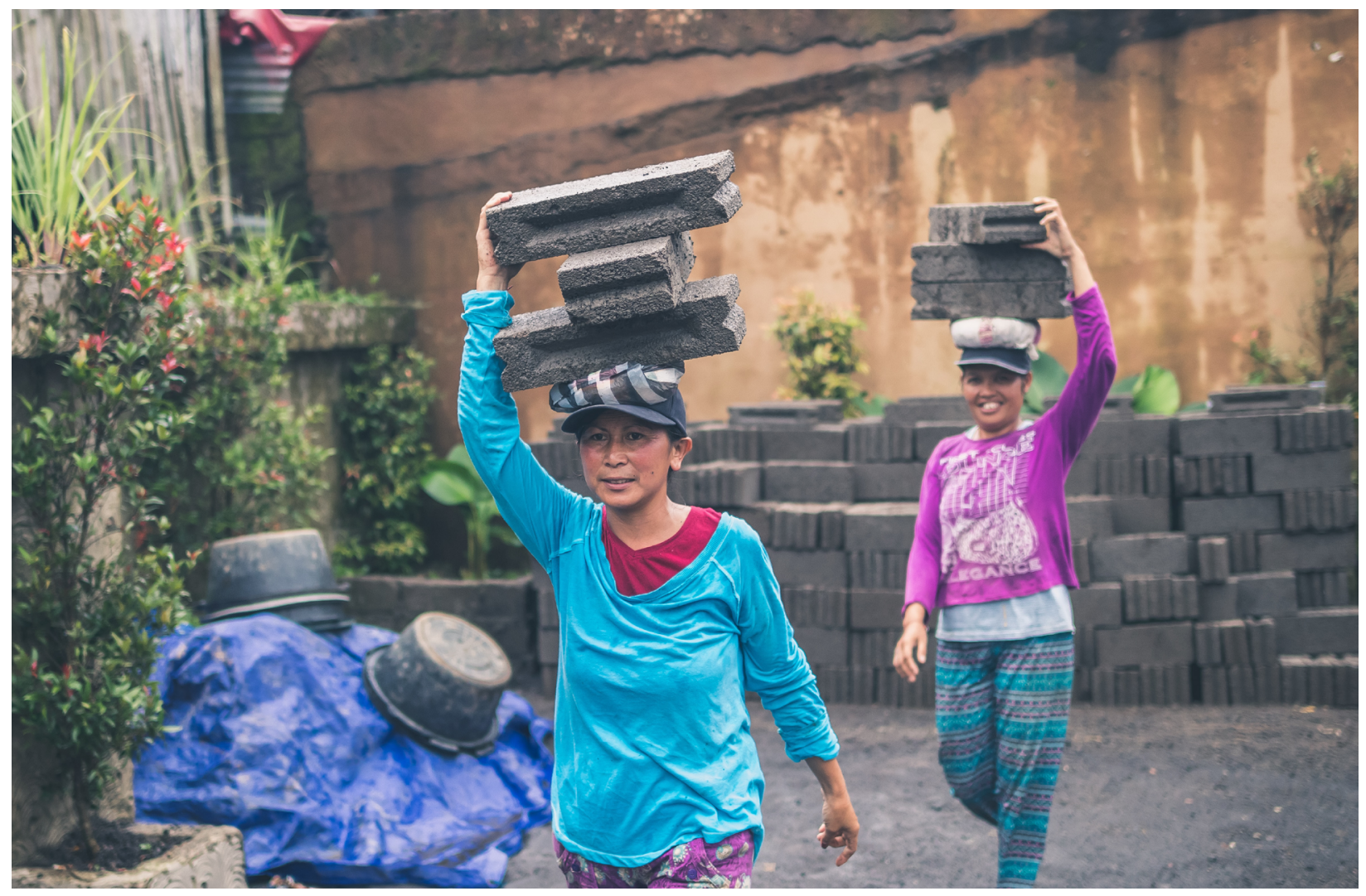

Access to quality healthcare and the right to free participation in social, economic, and political spheres of society are fundamental human rights and determinants for overall human well-being.10,11,12 The 1994 International Conference on Population and Development (ICPD) recognized that reproductive health and women's empowerment are intertwined and necessary to achieve gender equality and development goals. ${ }^{9}$ Almost 25 years ago, the Beijing Declaration and Platform for Action from the Fourth World Conference on Women affirmed that women's empowerment and full participation in all spheres of society are fundamental for the achievement of equality, development, and peace. ${ }^{13}$ More recently, the Sustainable Development Goals Agenda placed health and the empowerment of girls and women at the center of the development discourse. ${ }^{14}$ 


\section{PROGRESS IN WOMEN'S SEXUAL AND REPRODUCTIVE HEALTH}

\section{BOX 1. DEFINING SEXUAL \\ AND REPRODUCTIVE HEALTH'}

In 2018, the Guttmacher-Lancet Commission on Sexual and Reproductive Health and Rights developed a comprehensive and integrated definition of SRH. This was developed based on human rights and to raise the visibility of the needs of marginalized populations and foster strong, equitable, and holistic health systems that recognize and respond to essential needs of all across their lifespan. ${ }^{\mathbf{5}}$ The Commission defines SRH as the "state of physical, emotional, mental, and social well-being in relation to all aspects of sexuality and reproduction, not merely the absence of disease, dysfunction, or infirmity." SRH relies on realizing sexual and reproductive rights, including the right to bodily autonomy, privacy, safety, and access to care, counselling, information, and education, among others. Under this definition, reproductive health covers aspects of the reproductive health system, gender-based violence, contraception and family planning, maternal and newborn care, abortion and post-abortion care, menstruation, and infertility. ${ }^{\mathbf{5}}$

i For a full definition of sexual health, sexual rights, reproductive health, and reproductive rights, please visit: https://www.guttmacher.org/guttmacher-lancet-commission/accelerate-progress-executive-summary

A quarter of a century after the 1994 ICPD Plan of Action, there have been many improvements in women's SRH. The percentage of women of reproductive age that use contraception has increased by 25 percent globally from 1994 to 2019, and the adolescent birth rate has declined. ${ }^{15}$ Since 1994 , the total fertility rate has dropped from 2.9 children per woman in 1994 to 2.4 in $2016 .{ }^{16}$

Despite progress in women's reproductive health outcomes at the global level, substantial regional and national inequalities persist. Unmet need for family planning in developing countries is greatest among women in the poorest 20 percent of households. ${ }^{17}$ Additionally, in developing countries, women from the poorest 20 percent of households are more likely to have a child without a skilled birth attendant than women in the top wealth quintile.7 Inequality is also prevalent within some high-income countries, where aggregate numbers hide significant racial, ethnic, and socio-economic disparities related to maternal death and disability. ${ }^{18}$ Access to comprehensive reproductive health services, including modern contraception and safe abortion, is still a major challenge. ${ }^{18}$ Globally, 214 million women still have an unmet need for modern contraception, which means that they want to stop or delay childbearing, but are not using modern contraception. ${ }^{19}$ In developing regions, this unmet need can account for up to 84 percent of all unintended pregnancies. ${ }^{19}$ Globally, an estimated 25 million unsafe abortions take place each year. ${ }^{5}$ 
Increased investment in SRH is not only necessary to meet the demand, but also crucial to reap broad socioeconomic returns. At the individual level, access to modern contraception, safe and legal abortion, and the whole suite of SRH services, products, and information is critical to girls' and women's health, education, and participation in society and the economy. For example, fully meeting contraceptive needs in developing countries and providing comprehensive care for all pregnant women and newborns would reduce unintended pregnancies, unplanned births, and induced abortions. This would lead to an estimated 73 percent decrease in maternal deaths and 80 percent in newborn deaths. ${ }^{5}$ The provision of curriculum-based sexuality education can contribute to increased contraceptive use, ${ }^{20}$ which, in turn, could lead to a decrease in unintended pregnancy, and result in girls remaining in school. If girls and women are more empowered to decide if, and when, to have children, they have the potential to be more economically productive, increase their lifetime earnings, and realize their full economic potential. ${ }^{5}$ Women with limited educational or labor force opportunities in some contexts may perceive few options other than childbearing. Expanding access to schooling or economic opportunities may mean women choose to delay childbearing or have fewer children. ${ }^{21-23}$

\section{MEASURING AND ASSESSING WOMEN'S ECONOMIC EMPOWERMENT}

Despite progress, more work is needed globally to achieve gender parity in labor force participation and access to paid economic opportunities. In 2018, approximately 49 percent of women above the age of 15 participated in the global labor force compared to 75 percent of men. ${ }^{24}$ Moreover, as of 2018, more than 100 countries have laws preventing women from accessing the same choice of jobs as men..$^{25}$ Fully closing the gender gap in workplaces would add up to $\$ 28$ trillion in annual gross domestic product by 2025.

Not all labor force participation is equally empowering; work may be in the formal sector (e.g., salaried or hourly work) or in the informal sector (e.g., street vendors, domestic service, agricultural work, and others). ${ }^{26}$ Employment in the informal sector often does not confer the same benefits and security as work in the formal sector, such as labor rights and decent working conditions. ${ }^{27}$ While there are various types of informal work, women tend to be overrepresented in informal occupations that are characterized by low pay and a lack of social protection. ${ }^{28}$

Remuneration for work may be in the form of cash, in-kind (payment in the form of goods or services instead of money), or work can be unpaid (such as cultivating crops or working for a family member without direct payment). ${ }^{29-31}$ Women who are economically active, especially those who earn an income, have been shown in some contexts to be more likely to make major decisions about their own health and investments in assets, compared to their peers who are economically inactive. In addition, both conditional and unconditional cash transfer programs, which put money in the hands of women, have been found to be associated with increased educational attainment, lower fertility and pregnancy rates, and increased contraceptive use. This indicates that cash in hand may empower women to make 
decisions about their own health and education..$^{2-4}$ Cash earnings or access to cash can empower women in other domains of their lives, including increasing their ability to decide about contraceptive use. ${ }^{32}$

\section{BOX 2. DEFINING WOMEN'S ECONOMIC EMPOWERMENT}

There are many aspects to women's economic empowerment, including having the ability to participate in, contribute to, and benefit from economic opportunities such as jobs, financial services, assets, and information. ${ }^{\mathbf{3 3}}$ Additionally, women's economic empowerment should go beyond participation in economic opportunities, and should focus on the ability to succeed and advance oneself economically, combined with the power to make and act on financial decisions. ${ }^{\mathbf{3 4}}$ In summary, economic empowerment can be defined as "the transformative process by which women and girls go from having limited power, voice, and choice at home and in the economy to having the skills, resources, and opportunities needed to access and compete equitably in markets and the agency to control and benefit from economic gains." ${ }^{\prime 35}$

However, for women, having control over their own income is not always guaranteed. ${ }^{36}$ Compared to men, women are less likely to have control over how their earnings are used. ${ }^{36}$ In some contexts, employment has been shown to be empowering both economically and in other aspects of women's lives, when a person chooses to be in a job that provides earnings and leads to independent decision-making. Therefore, it is not just working, but the type of work, the type of remuneration, and control over that remuneration, that are important. ${ }^{37}$

\section{THE RELATIONSHIP BETWEEN SEXUAL AND REPRODUCTIVE HEALTH AND ECONOMIC EMPOWERMENT}

Many have theorized about the effects of economic empowerment on reproductive health outcomes. For example, studies show women with limited educational or labor force opportunities may perceive few options other than childbearing and put them at increased risk of adolescent pregnancies (Country Snapshot 1, p. 28). 21, 22, 23, 38

There are multiple ways in which the timing and number of children a woman has can affect her participation in the economic sphere. ${ }^{39}$ For example, postponing a first child until after adolescence has been linked with better educational outcomes and improved probability of working in the formal sector. ${ }^{40-45}$ In contrast, childbearing during adolescence can limit a woman's future economic 
opportunities by curtailing her schooling, and/or by compelling her to enter the labor force in lower paid, informal, or unskilled positions to support herself and her family.40, 41, 45, 46 However, this evidence is limited as it is primarily based on single-country studies.

A study in multiple low- and middle-income countries found that having fewer children at home is associated with higher levels of women's employment. ${ }^{39}$ Another global study found that as a country's fertility rates decline, women's labor force participation rates increase. ${ }^{47}$ These studies do not look at the types of employment, quality of the work women engage in, or how women are compensated for their work. ${ }^{48}$ Importantly, even if more women are "available" to participate in the labor force due to decreased fertility, factors such as the availability of labor opportunities for women, laws against gender discrimination in employment, amongst others may impede their participation. ${ }^{24}$

At the aggregate level there appears to be an association between fertility and women's labor force participation. However, it is not clear whether labor force opportunities drive lower fertility, or lower fertility rates free women to participate in the labor force. At the same time, we know a limited amount about whether fertility is related to the types of earnings women garner.

\section{This study adds to the current literature by exploring the relationship between adolescent childbearing and women's labor force participation and earning cash in 43 low- and middle-income countries. Few studies of low- and middle- income countries have considered whether the immediate consequences of an adolescent birth continue throughout a woman's lifetime.}

This study uses adolescent childbearing-one indicator of SRH-to specifically examine its association to women's economic empowerment, defined as being employed and earning cash (i.e., all forms of monetary payments). This association, disaggregated by age group, elucidates the short- and long-term economic impacts of adolescent childbearing on women's lives. This study suggests that cash earnings (as opposed to being paid in-kind), are the most empowering type of earnings, given the research linking cash earnings to economic empowerment. In addition, this study undertakes a descriptive analysis of married women's sole control over cash earnings to capture a broader perspective of economic empowerment. The study also presents recommendations to expand girls' and women's choices regarding when and how they begin childbearing, and the type of work they engage in throughout their lives. This is one of the first multi-country analyses to examine the short- and long-term impacts of having a child before 18 on employment and monetary compensation (cash earnings). 
PART II. Methodology 
In this study, the relationship between having a child during adolescence and women's employment in 43 low- and middle-income countries was examined. The 43 countries included in the analysis are home to more than 600 million women ages 20 to $49 .^{.}$

First, the study explores patterns of adolescent childbearing and employment for women across countries and regions. The study then examines, for women who were employed, whether they were paid in cash, in-kind, a combination of cash and in-kind, or were unpaid. Finally, it explores whether currently married women earning cash for their work are controlling the use of their earnings." Country-level regression models of the likelihood of being employed and working for cash by age group were estimated. Finally, a meta-analysis was carried out to summarize the country-level results.

ii In the Demographic and Health Surveys, only married/cohabiting women, who are employed and receiving cash earnings are asked about control over earnings.

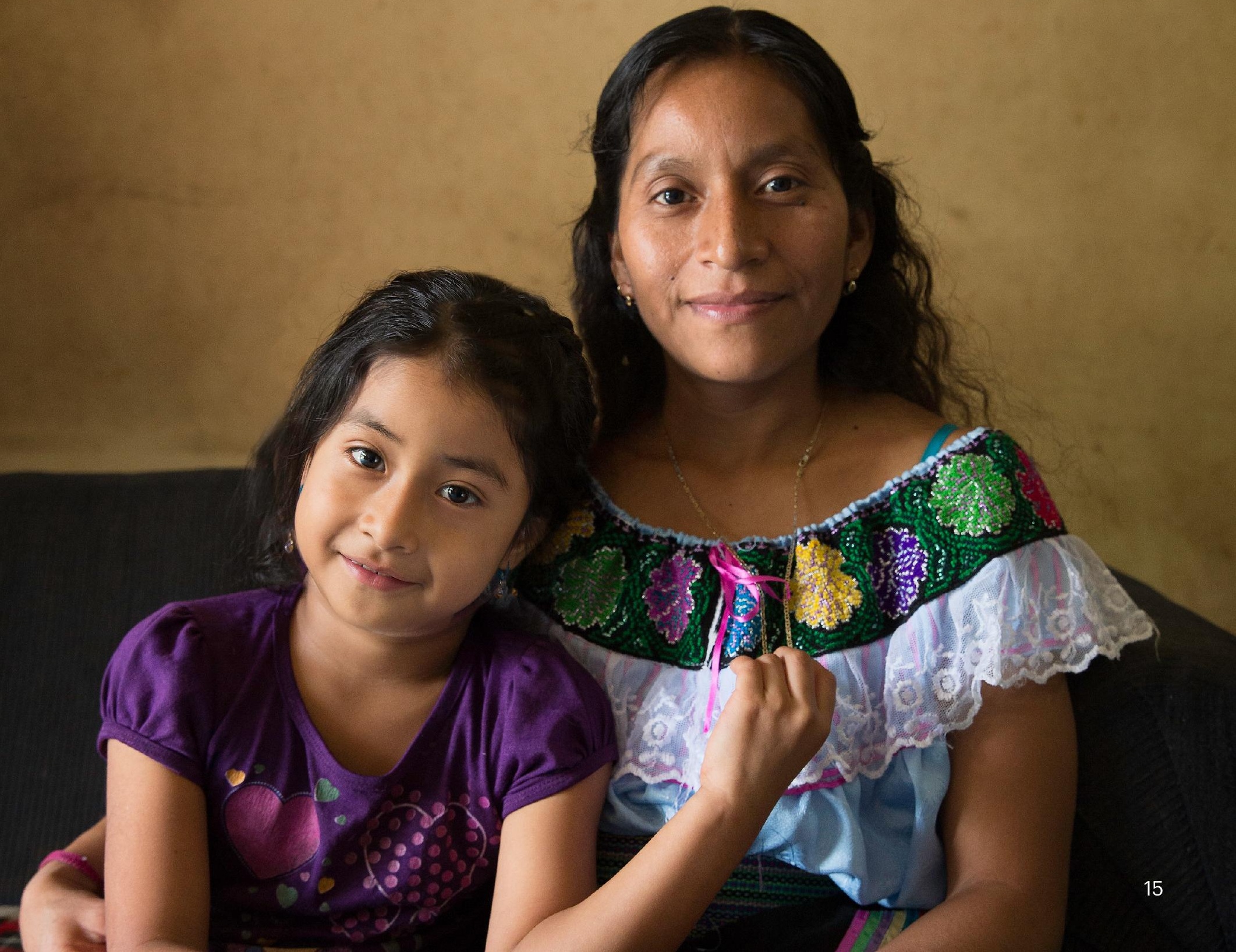




\section{DATA SOURCES AND INDICATORS}

\section{Data Sources}

Data from the most recent Demographic and Health Surveys (DHS) conducted between 2012 and 2018 for all women ages 20 to 49 were analyzed. The 43 countries for which surveys fall within the selected time-period, and sample sizes are detailed in Annex Table 1. DHS are nationally representative household surveys of women of reproductive ages (15 to 49). DHS were used for this work because they provide comparable, nationally-representative, recent data for many low- and middle-income countries. The surveys use standard questionnaires that collect information on fertility and women's employment, amongst other topics.

\section{Sexual and Reproductive Health Indicator Selected}

The DHS questionnaire collects information on a range of SRH outcomes. This study focuses on adolescent childbearing, or birth by age 18 , as it has been an important arena for primary research as well as interventions. ii The study categorizes women by whether they had a child by age 18 or not. This was constructed from the "age at first birth" variable, calculated by the DHS. The sample was limited to those ages 20 to 49 to exclude respondents for whom there is incomplete information on adolescent childbearing, as those ages 15 to 19 have not yet completed their exposure to the risk period (adolescence).

iii The variable used in this study represents live births; pregnancies that do not result in a live birth (i.e., spontaneous and induced abortions, miscarriage, and stillbirths) are not included.

\section{Economic Empowerment Indicators Selected}

Three variables on economic empowerment were constructed based on a series of questions asked in the DHS:

1. Employment in the past year, defined as currently working or having worked in the 12 months preceding the survey. This includes engaging in formal and informal work. It does not include the respondents' own housework or other domestic responsibilities, including care of her own children or relatives.

2. Cash earnings among women employed in the past 12 months, defined as having received payment in cash in exchange for work.

3. A woman's control over her own cash earnings, among those currently married or cohabiting, defined by whether the married woman usually decides herself how her earnings are used. 
The DHS questionnaire includes a series of questions for female respondents about whether they work, the type of work they do, and control over earnings. Women are first asked about work "aside from your own housework." Those who work (or have worked in the last 12 months) are asked whether they worked for cash, for payment in-kind, for a combination of cash and in-kind payment, or are unpaid. The study focuses on cash earnings as past research has indicated that women receiving cash are more likely to make decisions about their own health and education. ${ }^{12}$ In-kind payments are less likely to be economically empowering and do not provide financial independence as cash earnings do. ${ }^{49}$ For married/cohabitating women who report cash earnings, there is an additional question on "who usually decides" how the money she earns will be used. The paper focuses on the percent of women who state they usually have sole control over their earnings, as women who control their assets are better able to exercise their agency and make decisions. ${ }^{34}$

\section{DATA ANALYSIS}

The analysis compares the likelihood of being employed in the past 12 months (including women who are currently employed) among two groups of women-those who had a child during adolescence and those who did not. Next, the analysis considered whether women who were employed earned cash for their work or not. The analysis also describes whether or not married/cohabiting women who earn cash usually have sole control over their cash earnings.

Logistic regression models were estimated for each country to get national-level estimates of the strength and magnitude of the association between adolescent childbearing and employment. Several adjustment variables were also assessed (including household composition, education, and parity), but it was found that including them did not alter the main results presented in this study. Country-level coefficients were subsequently used in meta-regression models to produce estimates across countries, and results are reported by five-year age groups.

Data were analyzed using Stata, version 15.0. Sampling weights provided in the DHS data files were applied to account for survey design. 
PART III. Findings 


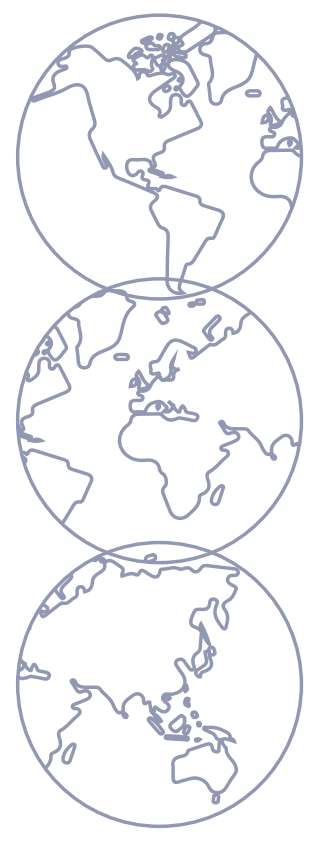

\section{ADOLESCENT CHILDBEARING AROUND THE WORLD}

Despite declines in some places, the prevalence of adolescent childbearing remains common in many countries, particularly in Sub-Saharan Africa, for the selected time-period (2012 to 2018; Figure 1, p. 20). Data from DHS during this time period show more than 20 percent of women ages 20 to 24 had a child by age 18 in 18 countries; of these, 16 countries were in Sub-Saharan Africa. Within Sub-Saharan Africa, the proportion of women ages 20 to 24 who had a child by age 18 varies widely, from 6 percent in Rwanda to 51 percent in Chad.

A birth during adolescence was rare (fewer than 10 percent) among women ages 20 to 24 years-old in 11 countries, including most of the Asian countries in the analysis. Moderate levels of adolescent childbearing (between 10 and 20 percent) are seen in 14 countries spread across all regions (Map 1).

\section{Map 1. The Prevalence of Adolescent Childbearing Among Women Ages 20 to 24*}

\section{Prevalence of Adolescent Childbearing}

High (>20\%)

Moderate (10-20\%)

Low $(<10 \%)$
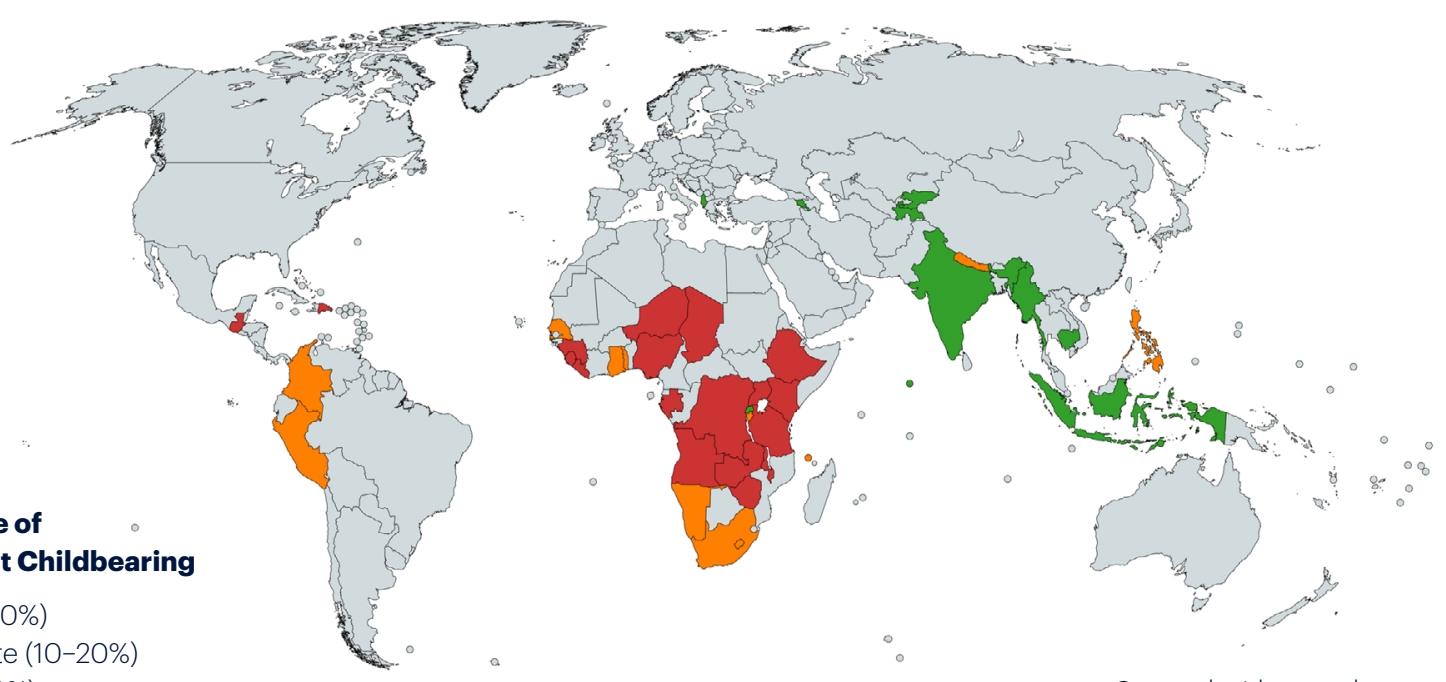

${ }^{*}$ Countries analyzed for the purpose of this study are highlighted in red, orange, and green.

In many countries, there was a large difference between the proportion of women ages 20 to 49 who had a child by age 18 and the proportion of women ages 20 to 24 who had a child by age 18, indicating that the incidence of birth by age 18 has changed over time. For example, in Ethiopia, 34 percent of women ages 20 to 49 had a child by age 18, while only 21 percent of women ages 20 to 24 had a child by age 18 , indicating a decline in adolescent childbearing. At the time of the survey, only four countries analyzed had a higher percentage of younger women compared to all women who experienced an adolescent birth: Angola, Chad, Niger, and the Philippines (Figure 1, p. 20). 
Figure 1. Percent of Women Who Had a Child by Age 18, by Country and Age Groups

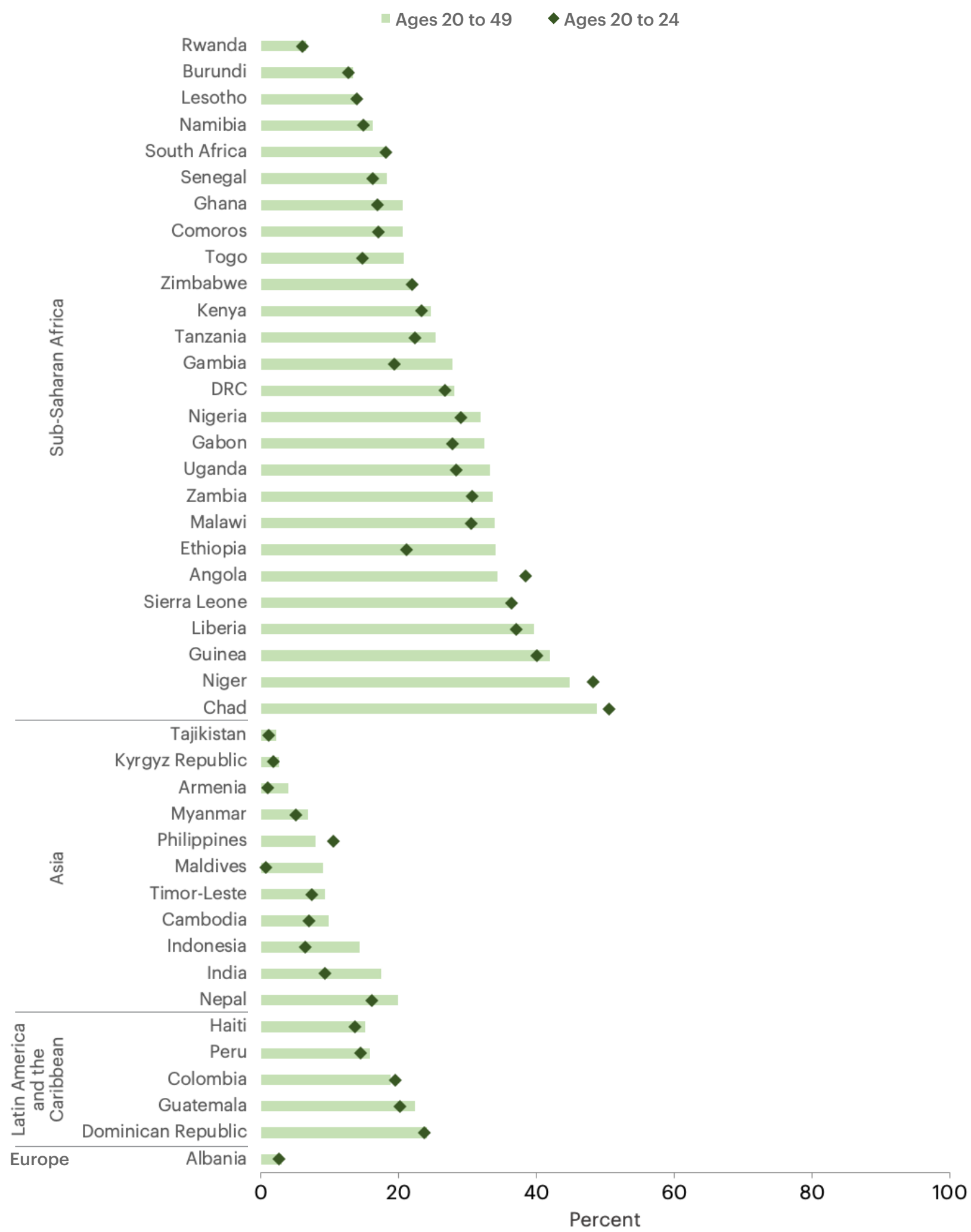




\section{WOMEN'S EMPLOYMENT AND EARNINGS AROUND THE WORLD}

\section{WOMEN'S EMPLOYMENT}

In 34 of 43 countries analyzed (more than three quarters of those included), at least half of women ages 20 to 49 were employed in the last 12 months (Figure 2, p. 22). This proportion, which captures employment in both the formal and informal economies, varies widely across and within regions. For example, among the Sub-Saharan African countries, there are several countries with very high levels of employment, including 13 countries where more than 70 percent of women report that they were employed in the last year. Among the Asian countries, at least 70 percent are working in Cambodia, Myanmar, and Nepal. In Latin America, Colombia and Peru have similarly high levels.

There is also considerable variation within regions; for example, among countries in West Africa, 31 percent of women are employed in Niger, while 85 percent of women work in Ghana. In Asia, the proportion of women employed ranges from approximately 33 percent in Tajikistan and India to 83 percent in Cambodia. Despite large differences in levels of employment across countries and regions, the patterns by age are similar. Across the age range from 20 to 49, employment in most countries tends to be lowest among women ages 20 to 24 years old and increases steadily with age, although there is a leveling off after age 40 in some countries (Annex, Table 2, p. 52). These patterns suggest that younger women may have less access to the labor market. 
Figure 2. Percent of Women Ages 20 to 49 Who Were Employed in the Past Year

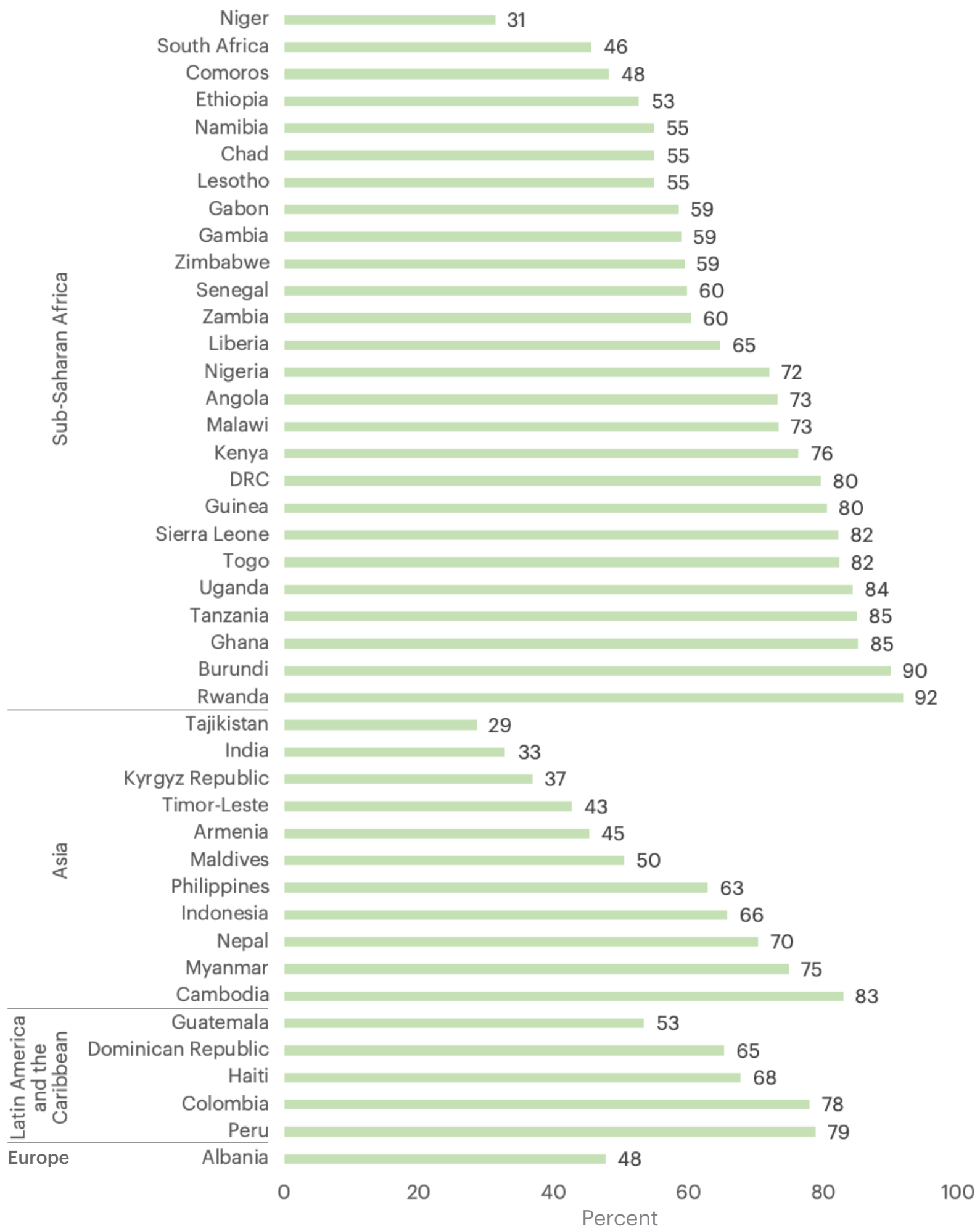




\section{TYPE OF EARNINGS}

Women who work may earn cash only, a combination of cash and in-kind payment, in-kind payment only, or be unpaid. Figure 3 (p. 24) presents the distribution of working women by type of earnings with the percentage who earn cash only, shown on the left side of each bar. The proportion of working women who earn cash ranges from less than 30 percent in Burundi and Rwanda to over 90 percent in Colombia, Guatemala, the Maldives, and South Africa. In 34 of 43 countries analyzed, more than half of women who work earn cash only, and in 19 countries, at least three-quarters of women who work earn cash only.

Unpaid work also takes up a significant share of employment in over half of the countries analyzed, even in countries where women are predominantly paid in cash. Of the 36 countries where cash is the most prevalent form of payment, unpaid work is the second most common form of employment in 22 countries. In an additional five countries analyzed (Burundi, Ethiopia, Malawi, Nepal, and Sierra Leone), unpaid work is the most common form of employment; in Sierra Leone and Malawi more than half of women report being unpaid for their work. In 11 of 43 countries at least one in four (25 percent) working women are unpaid.

In some countries, substantial proportions of women are paid both in cash and in-kind; in Burundi, the Democratic Republic of the Congo (DRC), Gambia, Rwanda, and Uganda, more than 25 percent of working women fall into this category. Haiti is notable in that almost half (48 percent) of working women receive both cash and in-kind payment. Receiving a good or a service in exchange for work instead of a cash payment can contribute to household and food security but does not promote women's financial independence. ${ }^{49}$

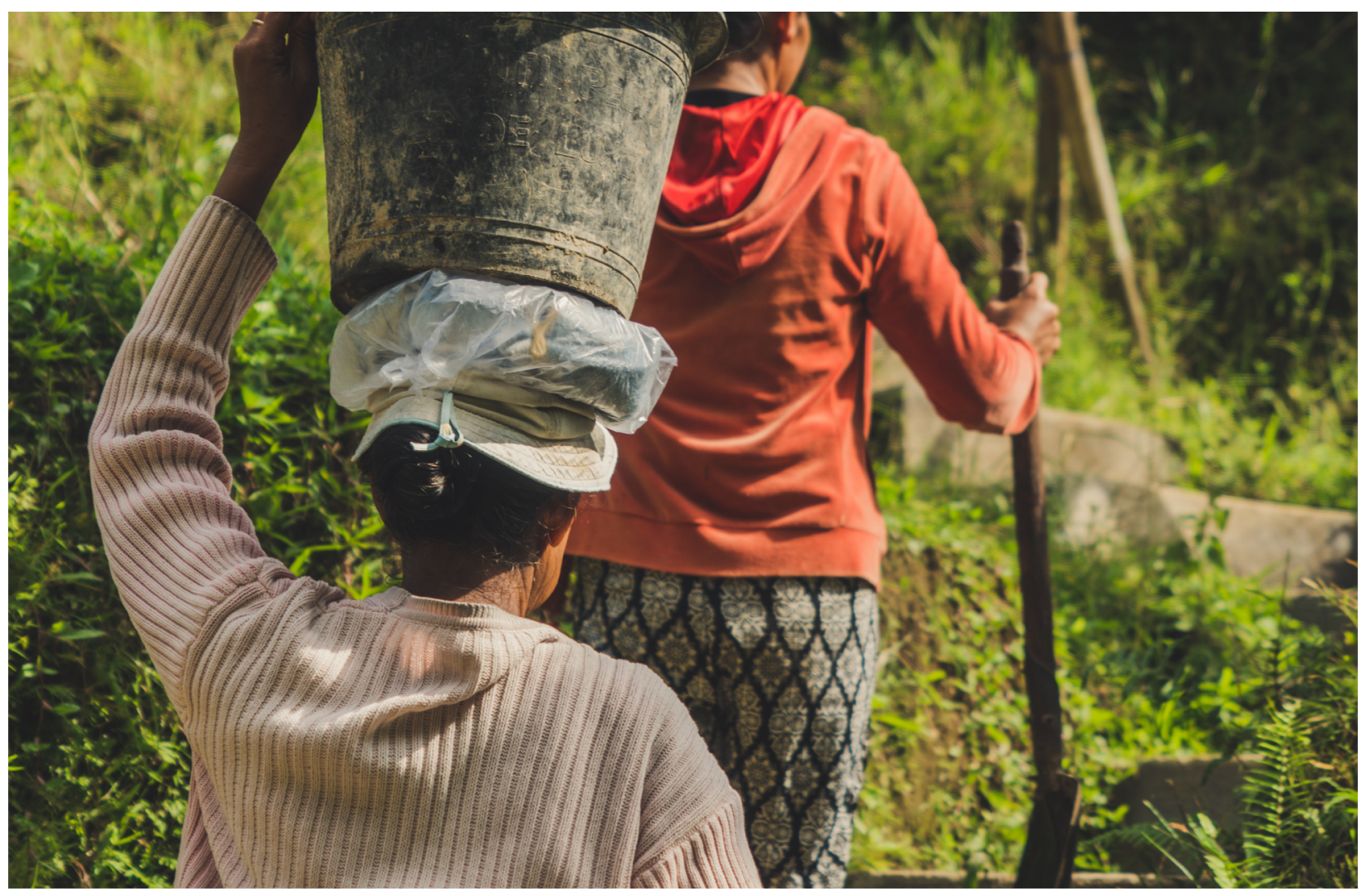




\title{
Figure 3. Percent Distribution of Women Ages 20 to 49 Who Worked in the Past Year, by Type of Earnings
}

acash only $\quad$ cash and in-kind $\quad$ in-kind only $\quad$ not paid $\quad$ missing/unknown

\author{
Burundi \\ Rwanda
}

Sierra Leone

Malawi

DRC

Ethiopia

Guinea

Uganda

Tanzania

Angola

Chad

Liberia

Comoros

Zambia

Ghana

Kenya

Gambia

Senegal

Togo

Zimbabwe

Nigeria

Niger

Lesotho

Gabon

Namibia

South Africa

Nepal

Timor-Leste

Indonesia

Armenia

India

$\frac{\pi}{40}$

Tajikistan

Philippines

Cambodia

Myanmar

Kyrgyz Republic

Maldives

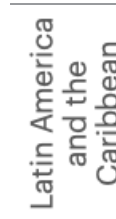

Europe

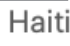

Peru

Dominican Republic

Guatemala

Colombia

Albania

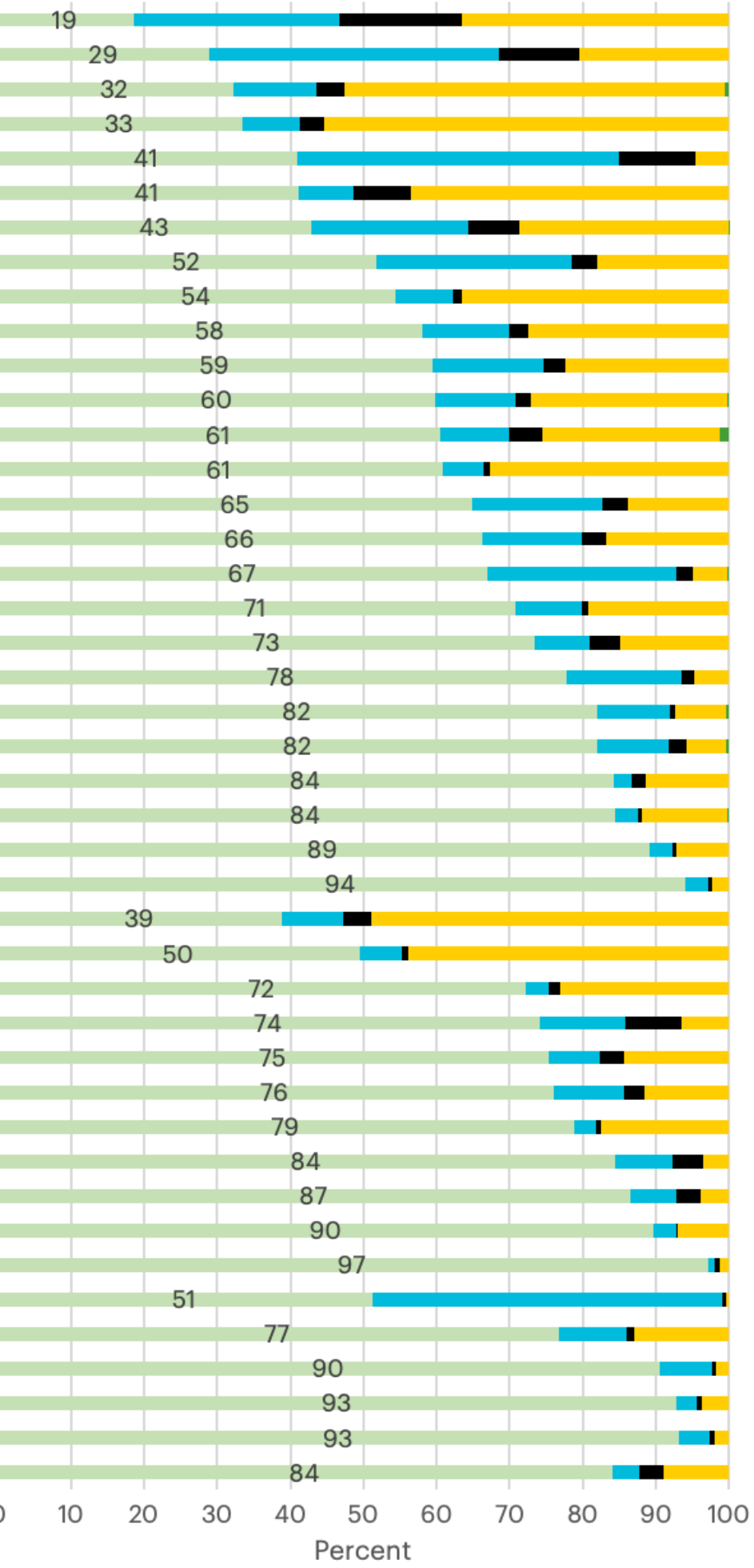




\section{RELATIONSHIP BETWEEN ADOLESCENT \\ CHILDBEARING AND ECONOMIC EMPOWERMENT}

\section{ADOLESCENT CHILDBEARING \\ AND WOMEN'S EMPLOYMENT}

The analysis shows that women ages 20 to 24 who had a child during adolescence were significantly more likely to be working at the time of the survey than women of the same age who did not have an adolescent birth (Figure 4). Women ages 20 to 24 with an adolescent birth are 1.2 times more likely to be working than their peers. This result is statistically significant. For older women (ages 25 to 49), the likelihood of working is the same whether or not they had a child during adolescence.

\section{Figure 4. Odds of Being Employed in the Past 12 Months After Having a Child by Age 18, by Age Group}

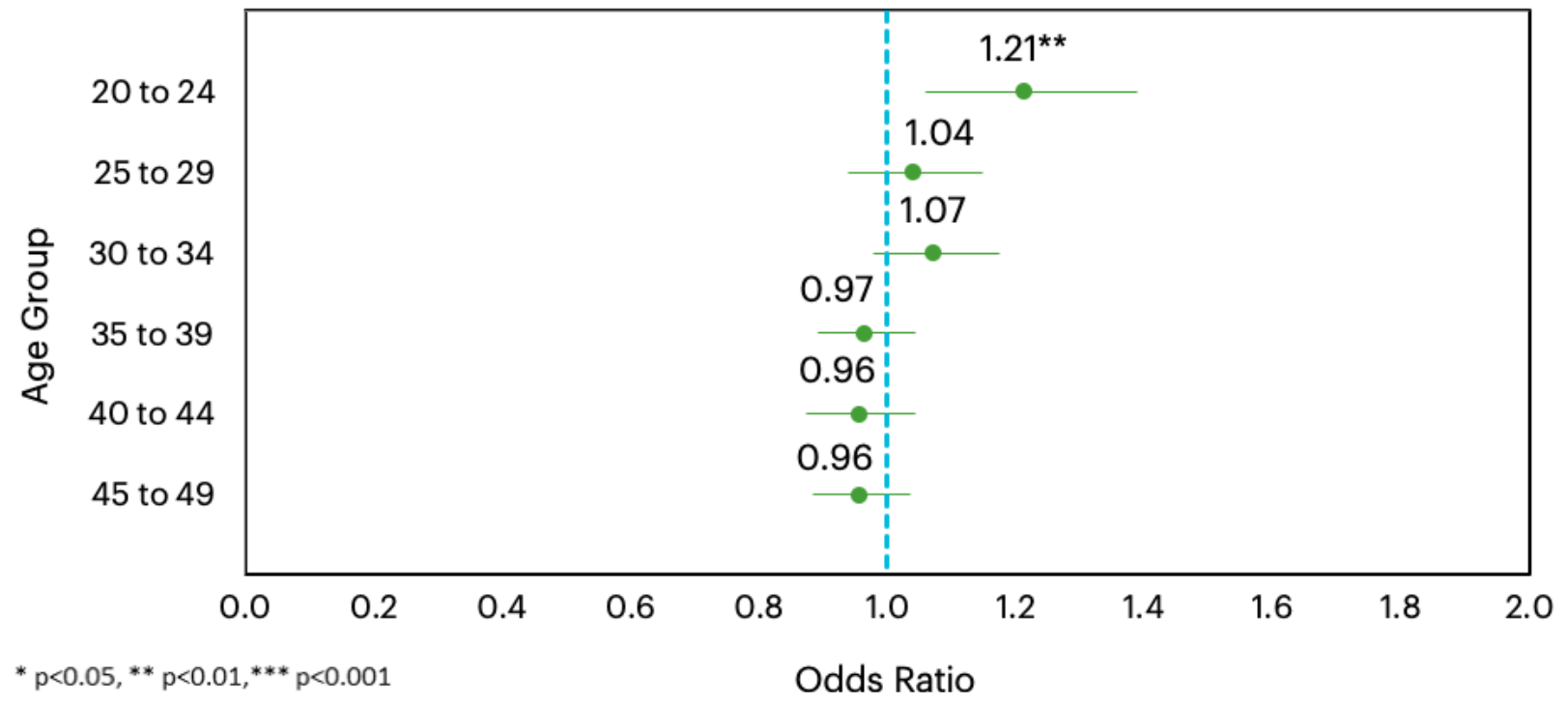

This pattern by age group may reflect that young mothers may be entering the workforce earlier than their peers in order to support themselves and their children. This study corroborates earlier findings that suggest early childbearing directly and indirectly compels young women to participate at higher rates in low-quality informal sector jobs possibly due to reduced educational outcomes and due to the reluctance of the formal employment sector to hire teenage mothers. ${ }^{40,41,45}$ The absence of the effect of an adolescent birth on women's employment among older women suggests that as she ages, other factors may play a greater role in determining whether she works or not. 


\section{ADOLESCENT CHILDBEARING AND CASH EARNINGS}

Further analysis of the subset of women who are working shows those who had a child by age 18 are significantly less likely to be receiving cash earnings than those who did not have a child by age 18.iv This relationship is statistically significant for all age groups (Figure 5).

\section{Figure 5. Odds of Earning Cash After Having a Child by Age 18 Among Women Employed in the Past 12 Months, by Age Group}

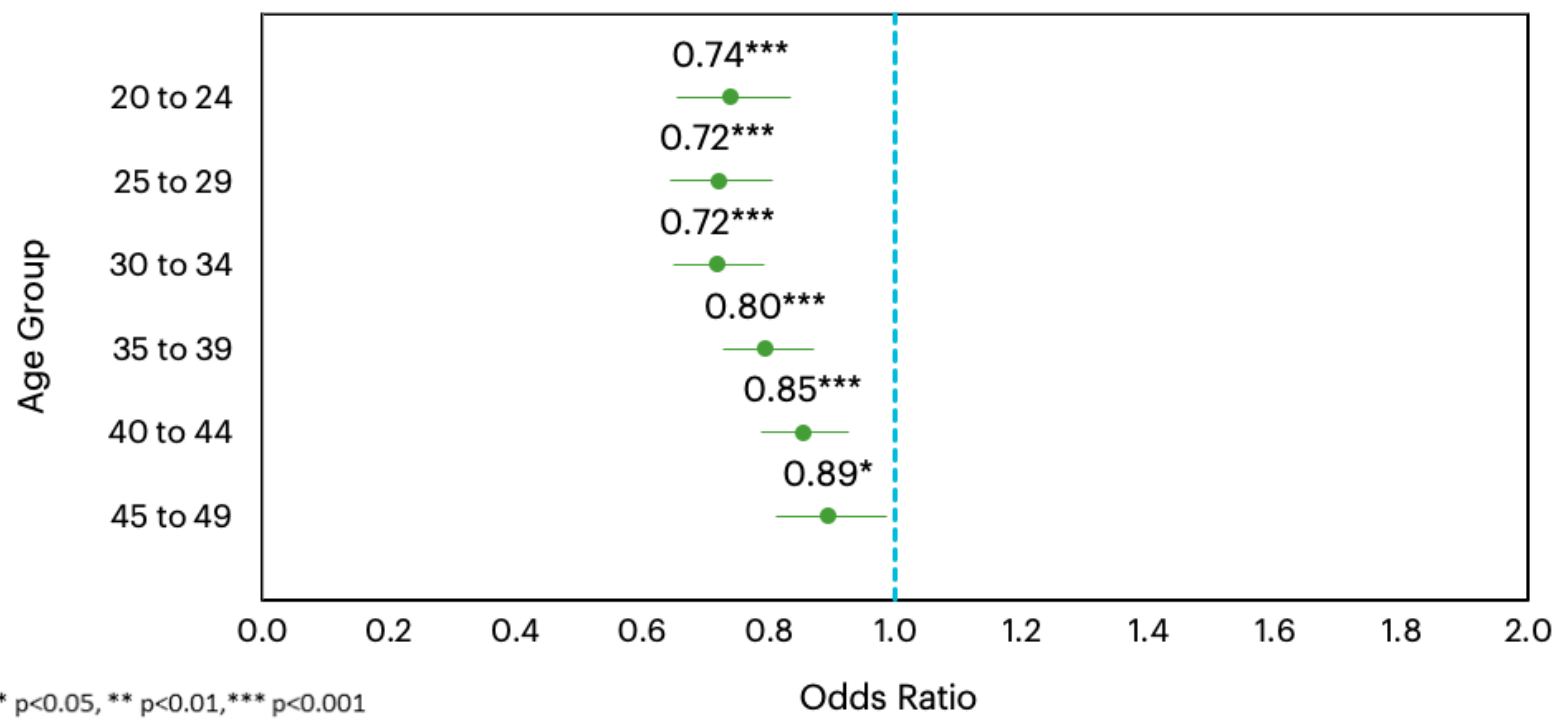

Having a child as an adolescent is associated with a 0.72 to 0.89 lower odds of receiving cash earnings, depending on age. This means women ages 25 to 49 who had a child before age 18 are less likely to earn cash than women of the same age who did not have a child before age 18, even though they are equally likely to be employed. Therefore, the concern is not only that young mothers may be initially pushed into unpaid jobs, but that they remain in employment opportunities with limited cash-earning potential across their lives. These findings suggest that the economic impact of an adolescent birth continues throughout a woman's life, negatively influencing the ability of women to engage in the type of empowering work that cash signifies.

The study suggests that women who have a child by age 18 may be set back economically throughout their reproductive life span. 


\section{PART IV.}

Country Snapshots 
Country Snapshot 1

\section{ADOLESCENT GIRLS EMPOWERMENT PROGRAM, ZAMBIA}

The relationship between adolescent childbearing and economic empowerment is complex. In Zambia, high adolescent pregnancy rates have been a concern for the government, and evidence suggests that these rates are not declining. ${ }^{38}$ Recognizing that adolescent girls in Zambia are often vulnerable and exposed to multiple risks, the Population Council implemented the Adolescent Girls Empowerment Program (AGEP), a program to build social, health, and economic assets of vulnerable girls ages 10 to 19. The goal of the program was to provide resources and tools to girls so that they would delay their first sexual interaction-a key moment that could increase their likelihood of completing school and decreasing the likelihood of marrying young and becoming pregnant. The intervention, which covered five urban and five rural sites, included a range of activities to promote girls' empowerment, including safe spaces, health vouchers, and savings accounts. AGEP was rigorously designed and evaluated. ${ }^{38}$

Qualitative results from AGEP show this complex interplay between pregnancy and transactional sex (sex in exchange for financial compensation or material goods).

"It was a kind of thing where you do not have things to use for the child like washing soap. So I met this guy who bought things like that and told me that he wanted to have sex with me and could not just give me for free. So I accepted and that was how I got pregnant." [Girl, 15 to 21, rural site]

Quantitative results of the study showed that transactional sex is not only an important driver of adolescent pregnancy, independent of other risk factors, but is a relatively common phenomenon: at baseline, 12.2 percent of girls in this analytical sample had engaged in transactional sex. At any given age, girls who have engaged in transactional sex are 1.37 times as likely as their peers who have not had transactional sex to have a premarital pregnancy, even when adjusting for socio-demographic risk factors such as school attendance, number of sexual partners, and orphanhood status $(p<0.01)$. When contraceptive use and other sexual behaviors are also adjusted for, at any given age, girls who have engaged in transactional sex are still 1.29 times more likely than their peers to have a premarital pregnancy $(p<0.05){ }^{38}$

The results of AGEP show that transactional sex, although a form of employment, is not economically empowering and may lead to adolescent pregnancy, which in turn can lead to school dropout and poor future employment outcomes.

For more information on AGEP, please see: https://www.popcouncil.org/research/adolescentgirls-empowerment-program 


\section{ADOLESCENT CHILDBEARING AND ECONOMIC OUTCOMES IN BIHAR, INDIA}

Globally, approximately one in five adolescents ages 10 to 19 years currently lives in India. ${ }^{50}$ The Government of India has articulated its commitment to protect and promote the health and rights of adolescents through the National Population Policy (2000) and the National Youth Policy (2014). ${ }^{51}$ A host of other policies and social sector programs have been implemented by the government, with funding from bilateral donors and multilateral agencies, to support adolescent and youth development and ensure a healthy, educated, and skilled future workforce. 52,53

Despite these programs, evidence on the health and development situation of adolescents and youth in India highlights that many Indian adolescents are lacking a complete or high-quality education, livelihood skills, employment opportunities, and healthcare. ${ }^{52}$ Socio-economic and gender gaps exacerbate these issues. ${ }^{54}$ Moreover, child marriage and adolescent childbearing remain common. According to this study's analysis of India's 2015 to 2016 National Family Health Survey (source for the DHS data), at the national level, 17.5 percent of women ages 20 to 49 gave birth by 18. Levels of employment among women in India are relatively low (33 percent of women ages 20 to 49), but among those who work, the majority earn cash (75 percent). Whether or not a woman had an adolescent birth also impacts her future employment in India; the study's analysis found that women ages 20 to 24 who gave birth by age 18 had 1.6 times the odds of working compared to women who had not given birth by age $18(\mathrm{p}<0.001)$. However, among women who worked, the odds of earning cash were the same among women who had given birth by age 18 compared to those who had not.

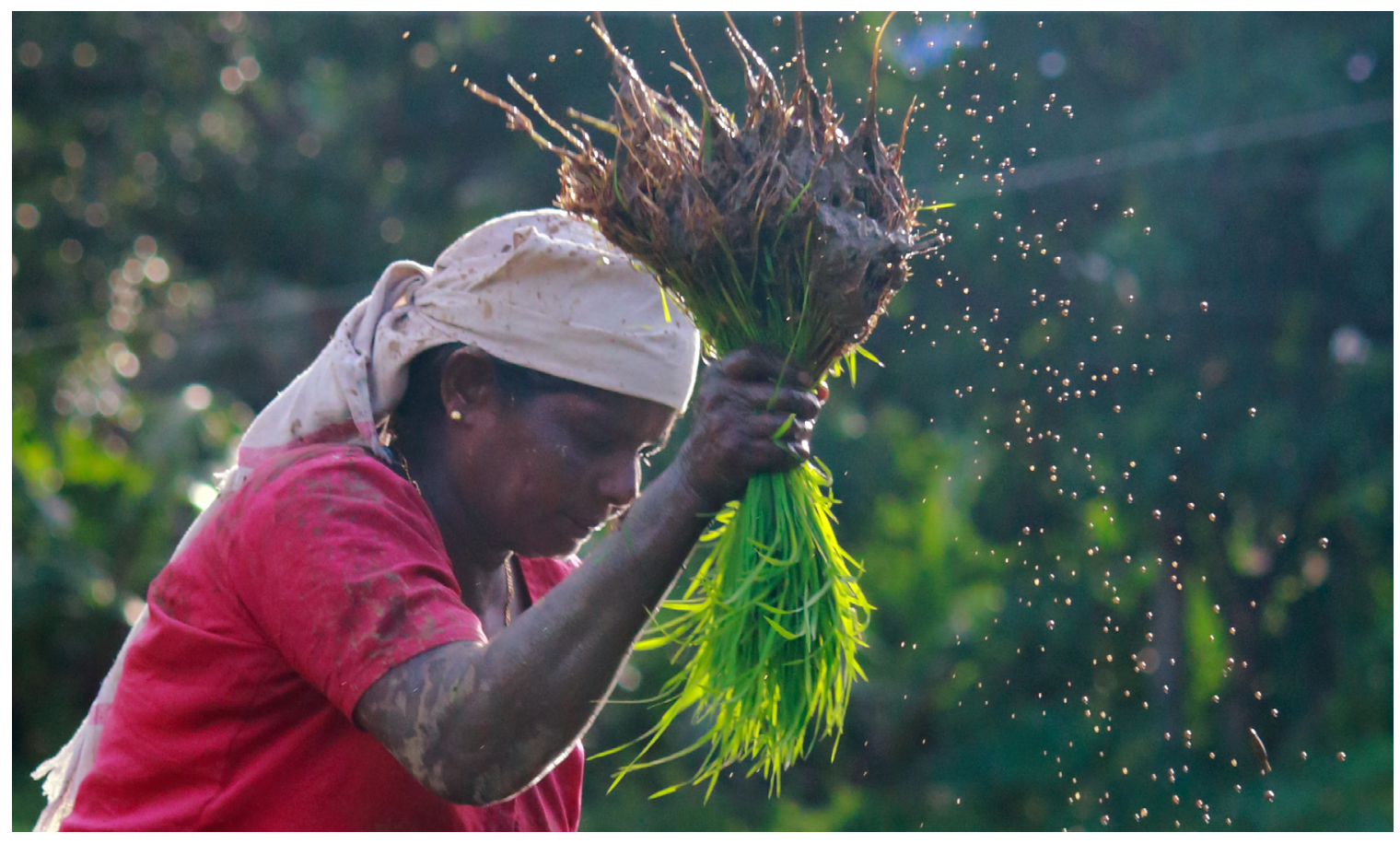


Sub-national analyses shed further light on the situation of adolescents and thereby help guide government and donors' efforts to improve investments for adolescents. The Understanding the Lives of Adolescents and Young Adults Survey (UDAYA), conducted by the Population Council in 2015 to 2016, collected state-representative data on the situation of adolescents and young people living in Bihar-one of India's most populous states.

UDAYA provides information on the association between adolescent childbearing and employment in Bihar. In 2015 to 2016, nearly 1 in 5 (18.7 percent) of the young women ages 23 to 27 surveyed had given birth before turning age 18, and nearly all women who reported an adolescent birth were married at the time of the birth. ${ }^{55}$ In keeping with this study's analysis, UDAYA data showed that the proportion of young women ages 23 to 27 in Bihar who reported working in the last 12 months was significantly higher among women who gave birth before age 18 (44.4 percent) compared to those who had not given birth by age 18 (27.6 percent, $p<0.001$ ) (data not shown). Additionally, the percent of all women ages 23 to 27 who reported working in exchange for payment ${ }^{v}$ ever, or in the past year, was significantly higher among women who gave birth by age 18 compared to those who did not (Figure 6). ${ }^{50}$

While not directly comparable to the multi-country analysis presented in the broader report, these findings support similar conclusions-that young mothers may face challenges such as having to work out of necessity after giving birth.

\section{Figure 6. Percent of Women Ages 23 to 27 Who Reported Working in Exchange for Payment, by Whether They Gave Birth by Age 18}

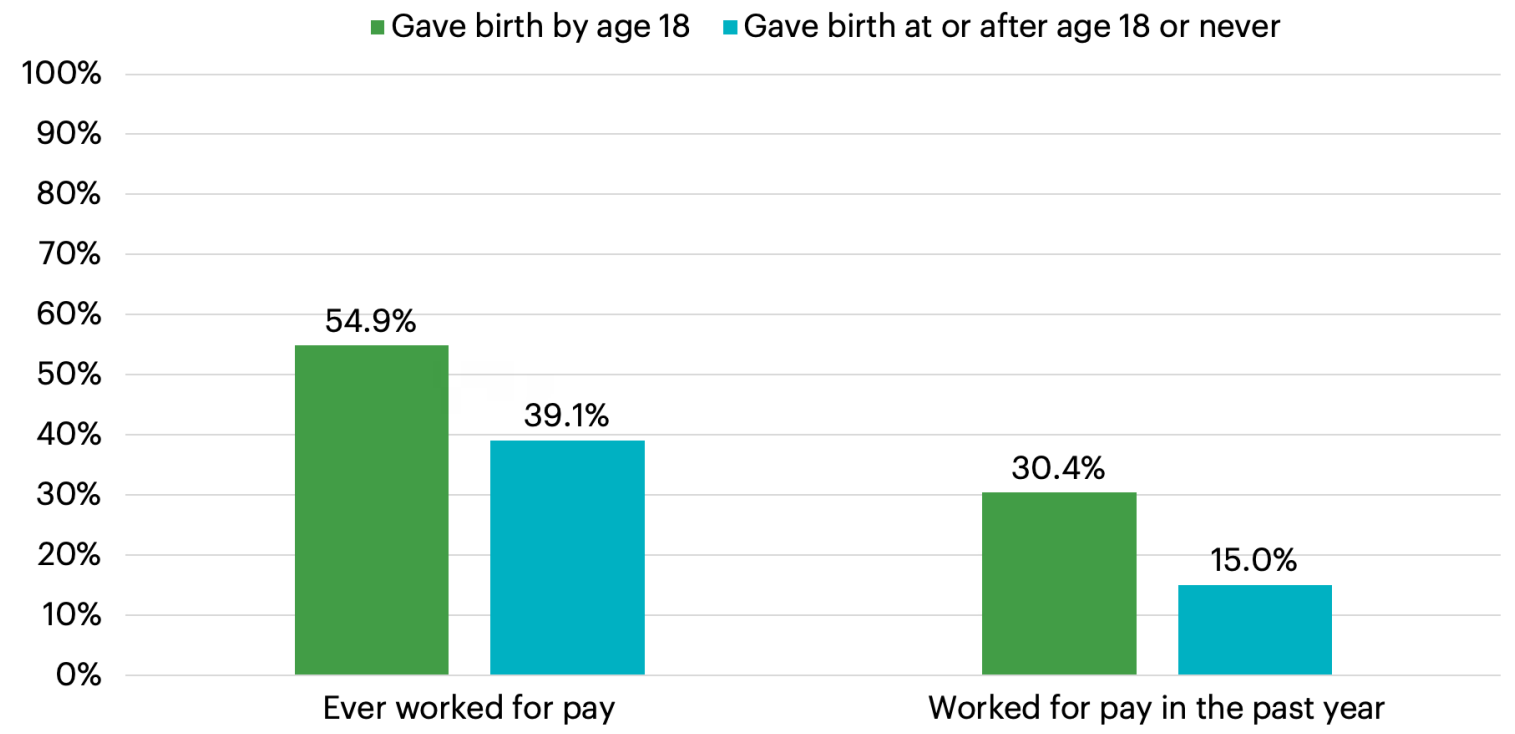




\section{PART V.}

Control Over Earnings: Descriptive Analysis 


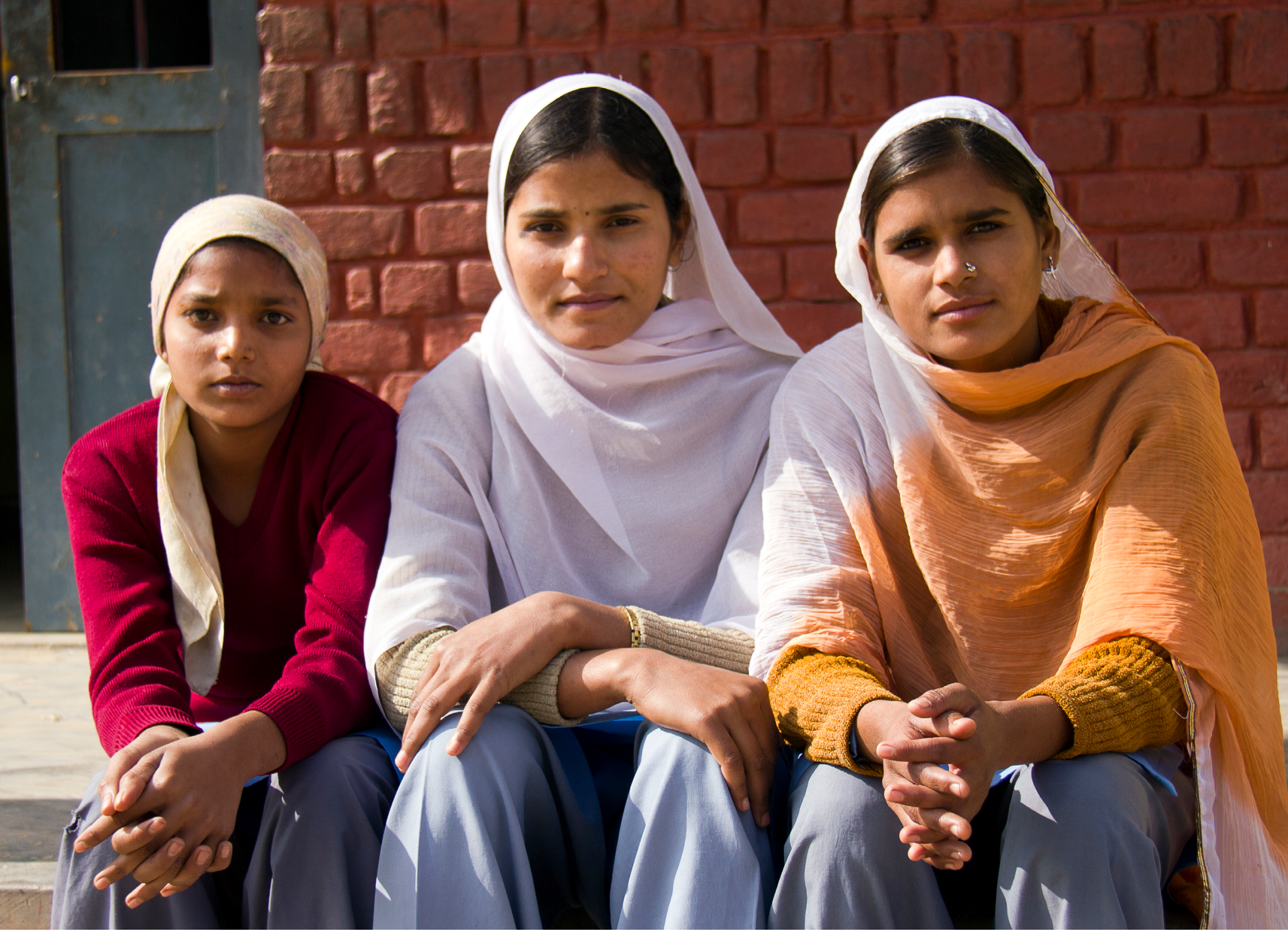

A descriptive analysis conducted for this report presents information on married/cohabiting women's sole control over earnings. ${ }^{\text {vi }}$ This is in an effort to capture a more realistic picture of married/ cohabiting women's economic empowerment levels in each country. While this analysis does not delve into the relationship between early childbearing and control over cash for this sub-sample of the population, the descriptive analysis is a key step in understanding the broader perspective of a woman's economic empowerment. Control over earnings is one indicator of a woman's agency, i.e., the ability to make and carry out decisions and choices for herself.

Three indicators for each country were calculated for this analysis:

1. The percent of married/cohabiting women who are working

2. The percent of married/cohabiting women who work and earn cash

3. The percent of married/cohabiting women who work, earn cash, and usually have sole control over how their earnings are used (Figure 7, p. 33). 


\section{Figure 7. Percent of Currently Married/Cohabiting Women Ages 20 to 49 Who Were Employed, Earning Cash, and Controlling Their Cash Earnings}

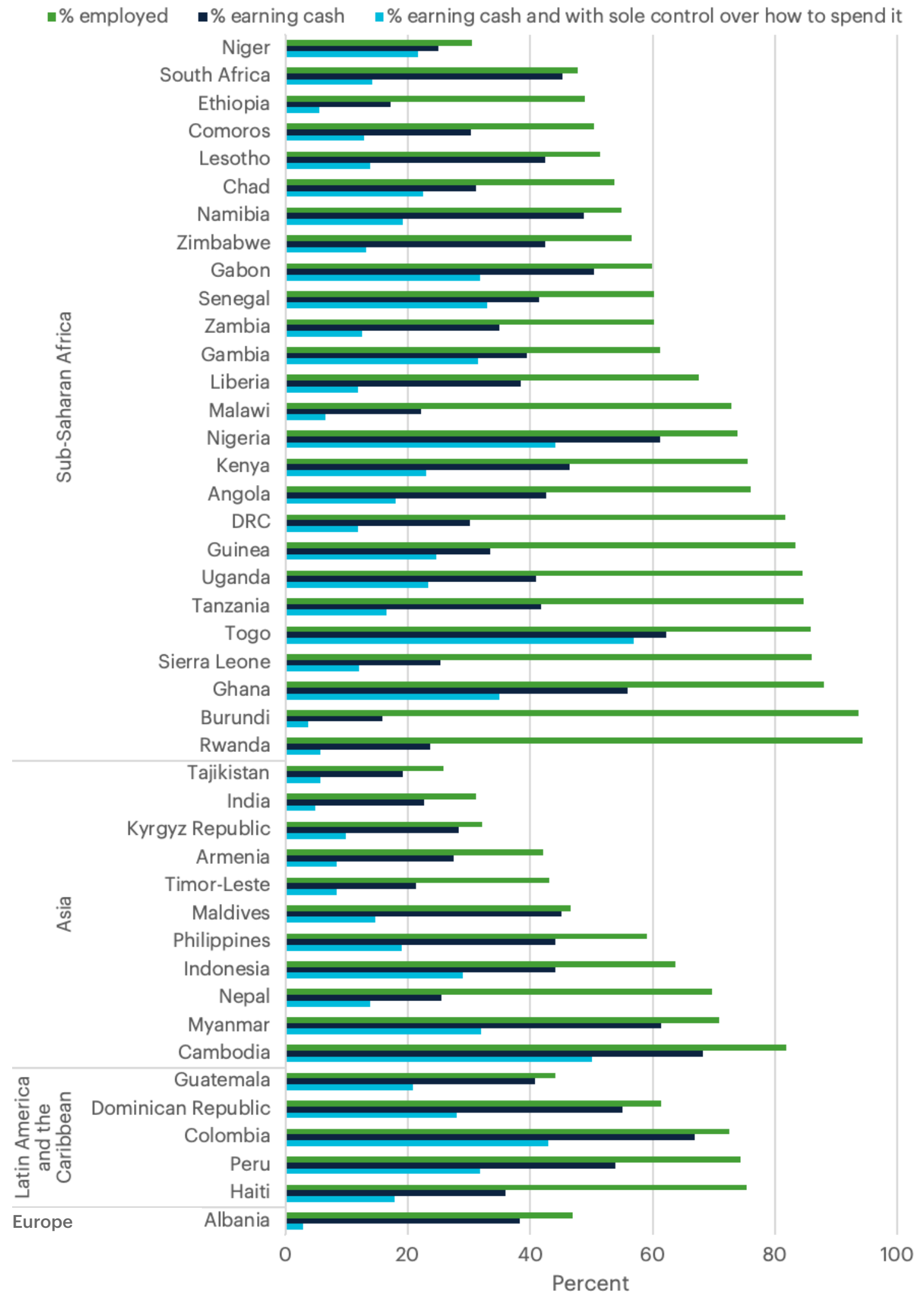


Women's economic empowerment is complex. These indicators together show the variation in overall patterns of control over earnings for married/cohabiting women. The following three examples serve to illustrate these differences and their implications for efforts aimed at advancing women's economic status and achieving gender equality:

\section{High levels of employment, and high levels of cash earnings, and control over earnings among those employed}

In Togo, most married/cohabitating women are employed (86 percent), a majority earn cash (62 percent), and usually decide alone how to control their cash earnings (57 percent). In this case, ensuring working women can continue to access economically empowering jobs that provide cash payments would be a priority, as most married/cohabiting women who earn cash for their work also control their earnings.

\section{High levels of employment, but low levels of cash earnings, and control over earnings among those employed}

In Burundi, even though the vast majority of married/cohabiting women are employed (94 percent), only one-sixth (16 percent) are receiving cash earnings and fewer than one in 20 women (4 percent) usually have sole control over their earnings. Therefore, to increase economic empowerment in Burundi, policies should focus on providing opportunities for women to enter the paid labor market.

\section{Low levels of employment, but high levels of cash earnings, and control over earnings among those employed}

In Niger, only 31 percent of married/cohabiting women are employed, but 25 percent earn cash and 22 percent usually have sole control over their earnings. Therefore, in Niger, if married/cohabitating working women earn cash, most of them are also likely controlling their earnings. However, since so few married/cohabiting women are employed, this finding represents a low proportion of married women overall and policies could focus on improving women's labor force participation overall.

While many findings are specific to each country, this analysis uncovers some overarching patterns regarding married/cohabiting women's economic empowerment. While in most countries (32 out of 43 countries analyzed) more than 50 percent of married/cohabiting women were employed, in few countries do most women work for cash (over 50 percent in nine countries). In only two countries do more than half of women work, earn cash, and control their earnings (Cambodia and Togo). These patterns allude to the importance of valuing women's work, increasing access to paid economic opportunities, and addressing imbalances in decision-making power. In most countries, many married 
women who do not usually have sole control over their earnings report that they jointly decide with their spouse how their earnings are used (data not shown).

It is important to note that if the proportion of women who are married/cohabiting in a country is low, the findings on control over earnings, which are collected only among married/cohabiting women, are less representative (Annex, Table 3, p. 53). Lack of data on unmarried girls and women who are working remain a barrier to a complete understanding of women's economic empowerment.

Control over cash for married women is an important empowerment variable to analyze in countries with high marriage rates, and in particular, high rates of child marriage. While not specifically considered in this report, as data on age of marriage were not included, there are clear links between child marriage and early childbearing and negative educational outcomes. ${ }^{40,46,56,57}$ Each of these factors, independently or together, directly and indirectly limit women's economic empowerment and merit further consideration.

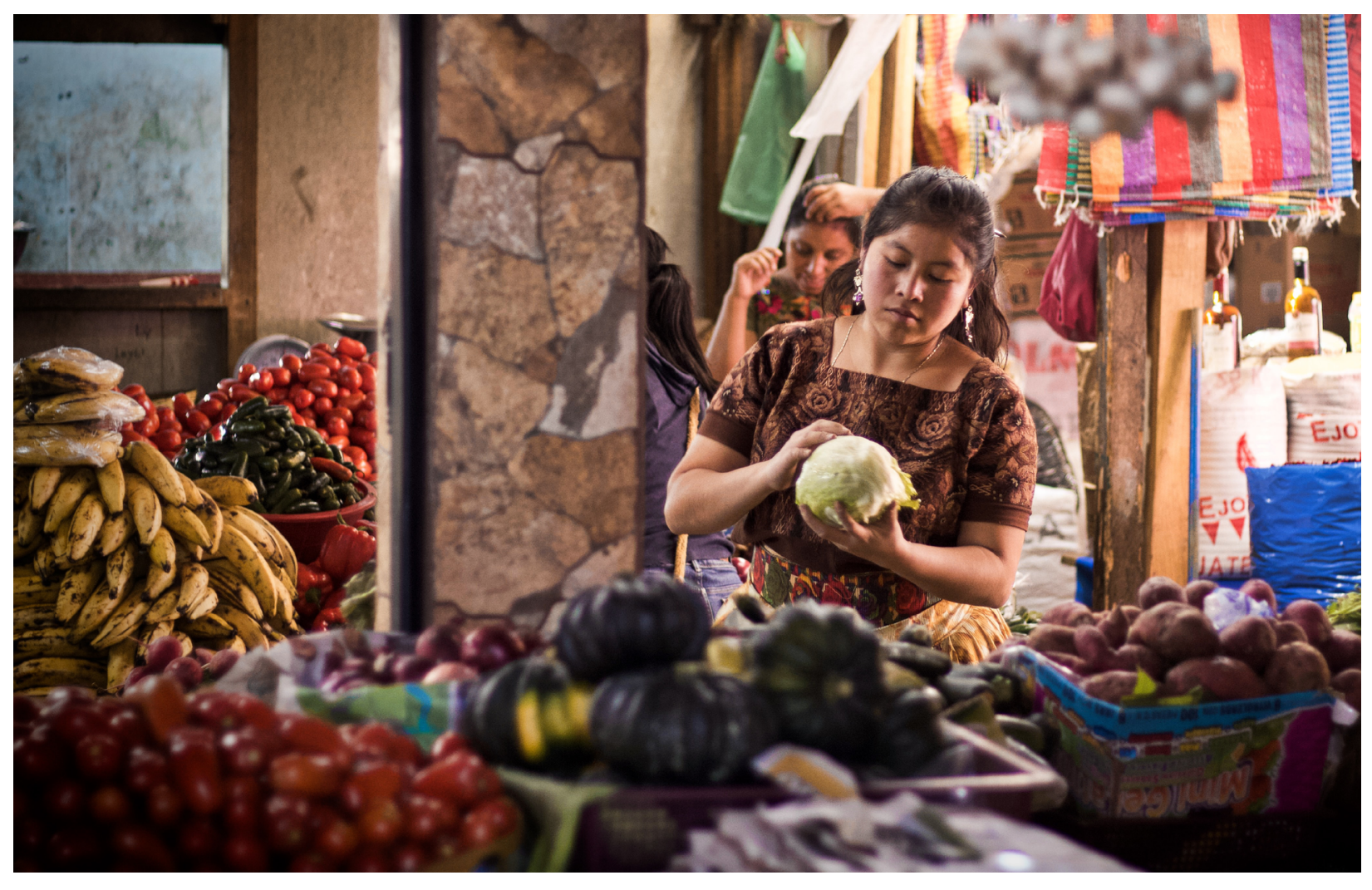


PART VI.

Study Limitations 


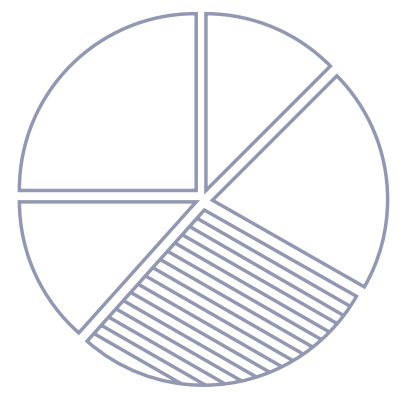

Due to the availability of comparable data, findings from this analysis pertain to low- and middle-income countries. While using DHS data enhanced the comparability and validity of the findings, it is a crosssectional survey that does not comprehensively capture all the nuances of the topic examined. For example, the lack of data on the amount of earnings or women's employment history as well as limited questions on control over cash earnings for unmarried women limit the depth of this study regarding women's agency. The use of cross-sectional data also limits our understanding of whether and how the impact of adolescent childbearing is sustained throughout a woman's lifetime. Future analysis of longitudinal data would enable us to account for any changes in the labor market that have altered the impact of adolescent childbearing on women's economic prospects over time.

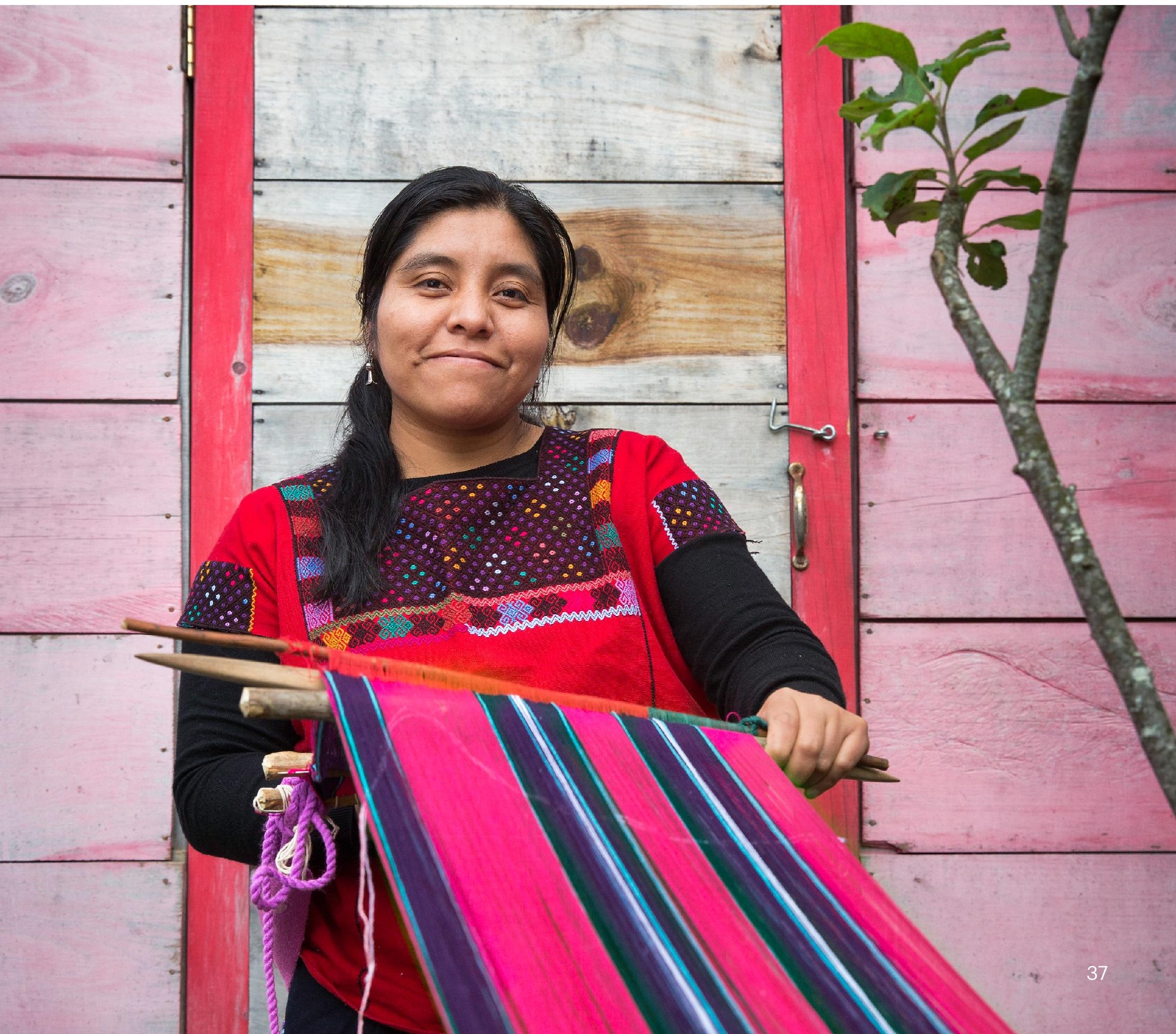


PART VII.

Conalusions 


\section{Results from this study indicate that adolescent childbearing is associated with lower levels of economic empowerment throughout the lifetime. ${ }^{\text {vii }}$}

vii When defined as being employed and working for cash.

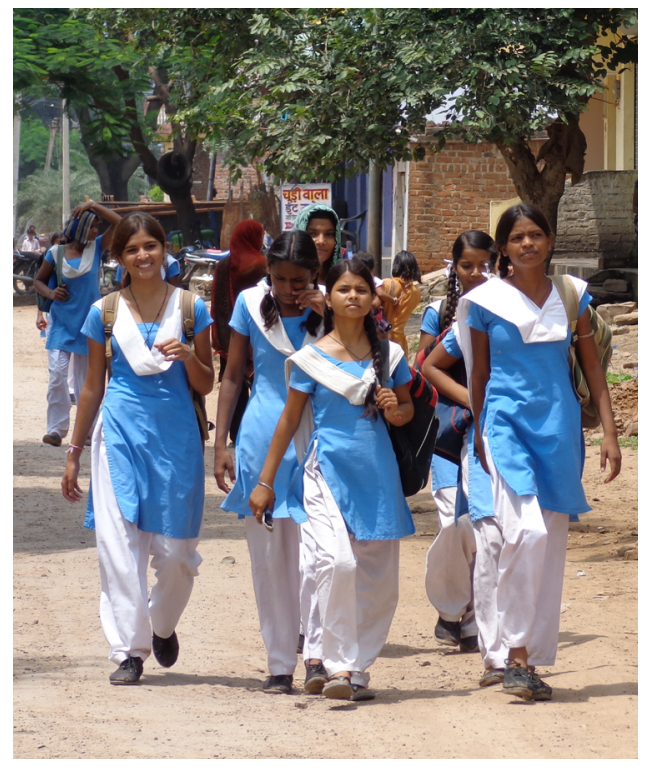

In fact, women ages 20 to 24 who have an adolescent birth are more likely to be employed, but less likely to be earning cash than their peers who did not have an adolescent birth. In most of the countries analyzed, the majority of women were employed, but whether they were paid in cash for their work varied widely. Unpaid work constituted a large proportion of women's work in several countries. Together, these associations suggest that in the countries analyzed, young women who had a child before age 18 are more likely to be in forms of employment that are unpaid or provide in-kind payments, limiting their cash earnings potential. Although adolescent childbearing is declining globally, it remains common in many countries, particularly in Sub-Saharan Africa.

Furthermore, this negative association between adolescent childbearing and earning cash for work is apparent for women throughout their reproductive years. The evidence suggests that even older women who had an adolescent birth had a significantly lower likelihood of earning cash, perhaps reflecting the challenge of shifting into paid work from less empowering work. Without cash earnings, and consequently no control over earnings, women who had a child during adolescence might have already adversely altered their trajectory for economic empowerment.

Women's control over their cash earnings is a marker of economic empowerment. While DHS data on control over earnings were only available for married/cohabiting women, the analysis found that the ability of married/cohabiting women to control their earnings varies widely across countries, but is generally low. In fact, in only two countries studied do more than 50 percent of currently married/ cohabiting women work, earn cash, and control their earnings. Though not assessed in this study, these findings are important in countries with high proportions of child marriage given the relationships between child marriage, early childbearing, educational outcomes, and economic empowerment. 40, 46, 56, 57

Taken together, these associations reflect a number of important life choices young mothers face, including working out of necessity after having a child, possibly in jobs that have limited opportunities for economic advancement.

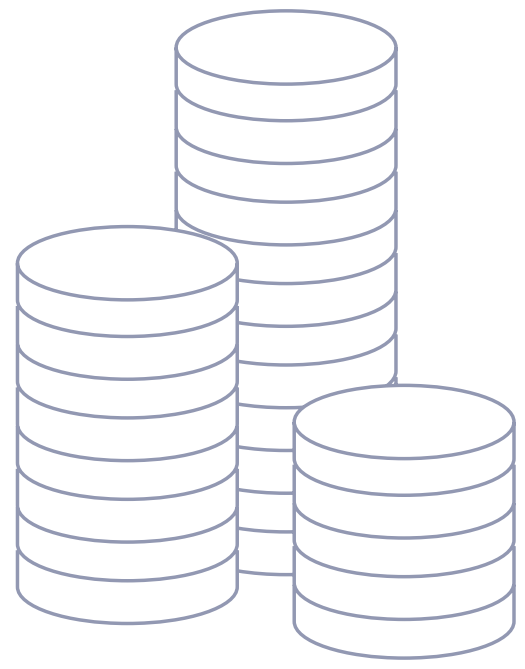


PART VIII. Recommendations 
The study suggests that progress is still to be made in providing every girl and woman with high-quality SRH services and enabling her full economic empowerment. Furthermore, the findings in this report highlight that these trends do not occur in isolation, as the ability to delay childbearing improves the chances of women to engage in economically empowering work. Therefore, improving access to adolescent SRH services and information for youth to reduce unintended pregnancies should be an essential component in efforts to improve women's economic empowerment. For mothers, reducing the constraints of adolescent childbearing and childrearing is also necessary. These efforts should be made in addition to improving women's participation in paid economic opportunities and control over earnings. Finally, various social, cultural, and political factors need to be taken into consideration when designing and implementing policies and practices aimed at increasing women's economic empowerment.

\title{
GOVERNMENTS, POLICYMAKERS, CIVIL SOCIETY, AND DONORS MUST COMMIT TO:
}

\section{Improve the provision of, and access to, high-quality, youth-friendly SRH services and information before, during, and after girls and women have children.}

\begin{abstract}
Integrate comprehensive SRH services, including those targeting youth, into the provision of primary healthcare and universal health coverage (UHC). Strengthen gender-sensitive health services that address gender-related barriers to healthcare; implement youth-friendly training, and guarantee the availability of affordable, accessible, and appropriate youth-friendly SRH services-including a wide range of discreet and on-demand contraceptive options, adequate counseling, confidentiality and privacy, friendly staff, short waiting times, safe abortion and post-abortion care, maternal and newborn care-free of stigma, discrimination, coercion, and violence.
\end{abstract}

Meaningfully engage youth in the design of programs and interventions related to their SRH. Involve youth, from design through dissemination, to increase ownership over programs and ensure their effectiveness.

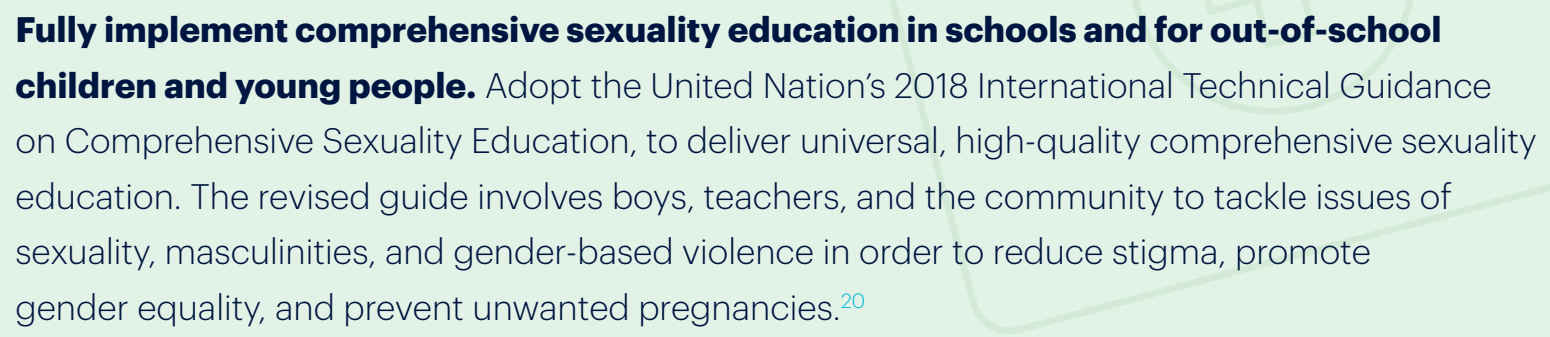




\begin{abstract}
Remove legal barriers that restrict access to SRH services and information and opportunities to make decisions about one's own body and fertility. Liberalize abortion laws to enable all adolescent girls and women to obtain safe abortion services. Remove restrictions involving parental or partner consent to access abortion services and family planning methods. Provide post-abortion care as a life-saving medical intervention and ensure adolescents can obtain post-abortion contraceptive information and services.
\end{abstract}

Increase investments in SRH programs, including those targeting youth. Implement gender-responsible budgeting and monitoring for sexual and reproductive services within UHC and minimize out-of-pocket payments for women over their life-course. This includes supporting community programming that provides SRH services.

\title{
2. Develop policies and programs to open-up a range of employment opportunities that are economically empowering for girls and women.
}

\begin{abstract}
Remove barriers that prevent teenage mothers from returning to school. Remove barriers such as abolishing education systems' policies that restrict or forbid pregnant girls and teenage mothers from staying in or returning to schools, or enforce hard social sanctions on pregnant girls and young mothers to enable girls to gain skills that prepare them to enter the paid labor market. Policies should facilitate safe environments in which girls can learn.
\end{abstract}

Increase girls' and women's marketable skills. Implement programs that develop girls' and women's skills, reflecting labor market demands, to increase their ability to enter the paid labor market. Examples of programs include internships, apprenticeships, mentoring programs, and training opportunities.

Invest in policies and social protection systems to create an enabling environment for women to enter and thrive in the formal and informal labor markets. Create an enabling environment for all women to access decent work. This includes strong social protection benefits such as parental leave policies, old-age pensions, flexible working hours, child allowances, social security, and establishing anti-harassment policies. Social protections should not be tied to employment contracts and should be legally available to informal workers. Implement measures to ensure pay is fair, reasonable, and meet the worker's needs should be implemented, such as prohibiting in-kind payments as part of minimum wage, or setting specific thresholds for in-kind payments. 
Improve data availability on the time spent working, including paid and unpaid employment outside the home, as well as housework and care work. In addition to paid and unpaid employment outside the home, women spend a significant amount of time on housework and care of others, such as children and other family members. Little is known about the total amount of time women spend working, and how housework and family care may affect women's participation in paid jobs.

Increase women's control over their cash earnings. This includes increasing access to comprehensive and equitable financial services, including credit, loans, savings, and insurance and removing any related legislative barriers. Programs and interventions must focus on increasing women's agency and meaningful participation in economic decision-making at the individual, household, and community levels.

\title{
3. Commit to collect nationally representative gender- and age-disaggregated data and use evidence to inform policies and practices.
}

\author{
Collect comprehensive, population-level data on issues related to girls and women, \\ disaggregated by gender and other demographic characteristics. There are insufficient data \\ on the amount of earnings and questions on control over cash earnings for unmarried women; \\ lack of data regarding SRH and decision-making ability of young adolescents and \\ unmarried women; lack of comprehensive measures of women's economic empowerment \\ and detailed longitudinal data on women's economic activities that capture changes during \\ important life transitions. To this end, it is important to facilitate partnerships between stakeholders \\ to coordinate data collection and management efforts, and ensure sufficient resources are \\ budgeted for regular collection of high-quality gender data.
}

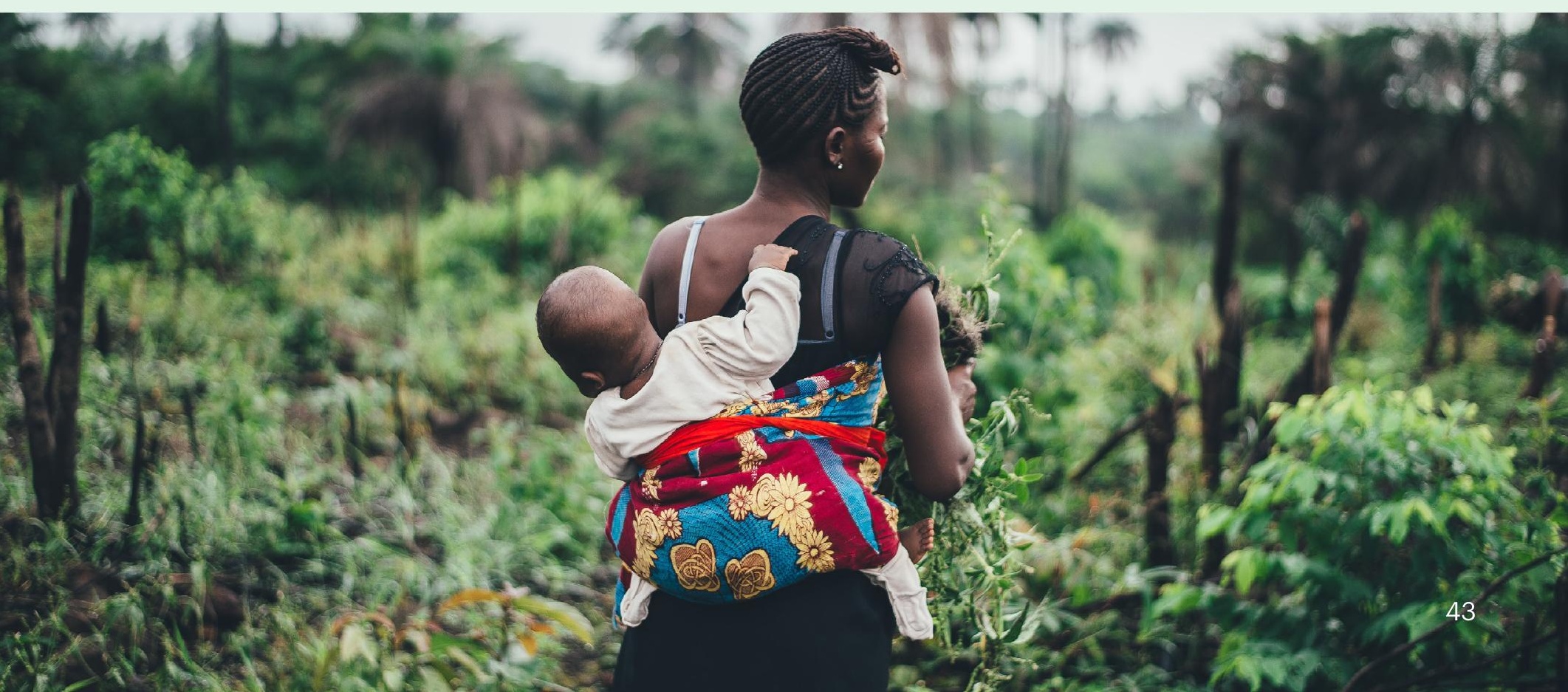




\title{
Beyond the implications of the results of this analysis, there are broader considerations to improve girls' and women's SRH and economic empowerment.
}

\author{
Enact and enforce comprehensive legal frameworks and policies to prevent early marriage \\ and violence against girls and women. Enforce laws and policies that prohibit marriage of girls \\ before age 18, establishing mechanisms for girls to report sexual harassment and violence and \\ mechanisms of redress. National-level child protection systems must be implemented \\ in addition to systems that connect girls and social networks in order to access social support.
}

\begin{abstract}
Address harmful gender norms and tackle stigma that limit girls' and women's health and agency. Implement gender-transformative interventions that target community members, including boys and men, to delay early marriage and improve uptake of modern contraception. Implement community programming around behavior change to promote gender equality, including interventions that inform and empower girls, such as comprehensive sexuality education, programming on sports that can increase girls' confidence, self-esteem, and agency; and programming to increase life skills such as communication and negotiation.
\end{abstract}

Mainstream gender across funding and programmatic decisions. Ensure the links between $\mathrm{SRH}$, economic empowerment, and broader development goals are adequately represented and included in funding decisions. Funding decisions should be transparent and well-coordinated amongst public and private financiers. Civil society should be involved in the creation of financing structures and national financing plans. Use reliable gender-disaggregated data to drive accountability efforts.

\section{NEXT STEPS FOR RESEARCH}

Further research at the national level could illuminate the influence of context on the relationships between adolescent birth, employment, type of earnings, and control over earnings. More qualitative studies are needed to better understand the choices girls and women make regarding their SRH (including decisions around getting pregnant, not using contraception, etc.) and employment (including being employed, not working for cash, etc.). In addition, studies that consider the intergenerational effects of SRH and economic empowerment are needed. Global studies that assess various components of SRH beyond adolescent childbirth are necessary to understand the role of $\mathrm{SRH}$ more broadly on women's economic empowerment. Finally, fully capturing the links between SRH and women's economic empowerment requires overcoming essential key data and knowledge gaps. Efforts and research towards filling these gaps are essential. 


\section{References}


1. Kabeer, N., S. Mahmud, and S. Tasneem. Does Paid Work Provide a Pathway to Women's

Empowerment? Empirical Findings from Bangladesh. Vol 375. Brighton, UK: Institute of Development Studies, 2011.

2. Rosenberg, M., A. Pettifor, and N. Nguyen, et al. Relationship Between Receipt of a Social Protection Grant for a Child and Second Pregnancy Rates among South African Women: A Cohort Study. PLoS One 10, no. 9 (2015): 1-12. doi:10.1371/journal.pone.0137352.

3. Darney, B.G., M.R. Weaver, and S.G. Sosa-Rubi, et al. The Oportunidades Conditional Cash Transfer Program: Effects on Pregnancy and Contraceptive Use Among Young Rural Women in Mexico. Int Perspect Sex Reprod Health 39, no. 4 (2013): 205-14. doi:10.1363/3920513.

4. Khan, M.E., A. Hazra, A. Kant, and M. Ali. Conditional and Unconditional Cash Transfers to Improve Use of Contraception in Low and Middle Income Countries: A Systematic Review. Stud Fam Plann 47 no. 4 (2016): 371-83. doi:10.1111/sifp.12004.

5. Starrs, A.M., A.C. Ezeh, G. Barker, et al. Accelerate Progress-Sexual and Reproductive Health and Rights for All: Report of the Guttmacher-Lancet Commission. Lancet 391, no. 10140 (2018): 2642-92. doi:10.1016/S0140-6736(18)30293-9.

6. Woetzel, J., A. Madgavkar, and K. Ellingrud, et al. The Power of Parity: How Advancing Women's Equality Can Add \$12 Trillion to Global Growth. New York: McKinsey Global Institute, 2015.

7. FP2020. Family Planning's Return on Investment. Washington, D.C: United Nations Foundation, 2018.

8. United Nations DESA/Population Division. World Population Prospects 2017. 2019. United Nations, https://population.un.org/wpp/ (accessed April 15, 2019).

9. United Nations Population Fund. Programme of Action of the International Conference on Population Development. New York: United Nations, 2014.

10. United Nations General Assembly. Convention on the Elimination of All Forms of Discrimination against Women. New York: United Nations, 1979.

11. United Nations General Assembly. International Covenant on Civil and Political Rights. New York: United Nations, 1966.

12. World Health Organization. Constitution of the World Health Organization. Geneva: World Health Organization, 2006.

13. United Nations. Beijing Declaration and Platform for Action. New York: United Nations, 1995.

14. United Nations. Transforming our World: The 2030 Agenda for Sustainable Development. New York: United Nations, 2016.

15. United Nations Population Fund. International Conference on Population and Development. 2019. United Nations. https://www.unfpa.org/icpd (accessed April 10, 2019).

16. The World Bank. Fertility Rate, Total (Births per Woman). 2019. The World Bank, https://data. worldbank.org/indicator/sp.dyn.tfrt.in?end=2016\&start=1994 (accessed April 10, 2019).

17. UNFPA. State of World Population 2017: Worlds Apart. Reproductive Health and Rights in an Age of Inequality. New York: United Nations, 2017. 
18. Grobman, W.A., J.L. Bailit, and M.M. Rice, et al. Racial and Ethnic Disparities in Maternal Morbidity and Obstetric Care. Obstet Gynecol 125, no. 6 (2015): 1460-67. doi:10.1097/AOG.0000000000000735.

19. Darroch, J., S. Audam, and A. Biddlecom, et al. Adding It Up: Investing in Contraception and Maternal and Newborn Health. New York: Guttmacher Institute, 2017.

20. United Nations Educational Scientific and Cultural Organization. International Technical Guidance on Sexuality Education: An Evidence-Informed Approach. Revised Ed. New York: UNESCO, 2018.

21. Canning., D, and T.P. Schultz. The Economic Consequences of Reproductive Health and Family Planning. Lancet 380, no. 9837 (2012): 165-71. doi:10.1016/S0140-6736(12)60827-7.

22. Jensen, R. Do Labor Market Opportunities Affect Young Women's Work and Family Decisions? Experimental Evidence from India. Q J Econ 127, no. 2 (2012): 753-92. doi:10.1093/qje/qjs002.

23. Duflo, E., P. Dupas P, and M. Kremer. Education, HIV, and Early Fertility: Experimental Evidence from Kenya. Am Econ Rev 105, no. 9 (2015): 2757-97. doi:10.1257/aer.20121607.

24. International Labour Office. World Employment and Social Outlook - Trends for Women 2018 Global Snapshot. Geneva: International Labour Office, 2018.

25. The World Bank. Women, Business and the Law 2018. Washington, D.C.: The World Bank, 2018. doi:10.1596/978-1-4648-1252-1.

26. Hussmanns, R. Statistical Definition of Informal Employment: Guidelines Endorsed by the Seventeenth International Conference of Labour Statisticians (2003). Geneva: International Labour Office, 2004.

27. International Labour Office. Women and Men in the Informal Economy: A Statistical Picture (Third Edition). Geneva; International Labour Office, 2018. doi:10.1179/bac.2003.28.1.018.

28. International Labour Office. Women at Work: Trends 2016. Geneva: International Labour Office, 2016. doi:ISBN 978-92-2-130795-2.

29. Razavi, S., and L. Turquet. Progress of the World's Women 2015-2016: Transforming Economies, Realizing Rights. Glob Soc Policy An Interdiscip J Public Policy Soc Dev 16, no. 1 (2016): 86-93. doi:10.1177/1468018115624314.

30. Finlay, J., Y. Efevbara, J. Ndikubagenzi, M. Karra, and D. Canning. Reframing the Measurement of Women's Work in the Sub-Saharan African Context. Work Employ Soc., 2018:1-11.

31. Organisation for Economic Co-operation and Development. Glossary of Statistical Terms. 2001. Organisation for Economic Co-operation and Development. https://stats.oecd.org/glossary/detail. asp?ID=2289 (accessed March 20, 2019).

32. Hagen-Zanker, J., L. Pellerano, and F. Bastagli, et al. The Impact of Cash Transfers on Women and Girls: A Summary of the Evidence. London: ODI, 2017.

33. Organisation for Economic Co-operation and Development. OECD Women's Economic Empowerment. 2018. Organisation for Economic Co-operation and Development. http://www.oecd. org/dac/gender-development/womenseconomicempowerment.htm (accessed June 25, 2019).

34. Golla, A.M., A. Malhotra, P. Nanda, and R. Mehra. Understanding and Measuring Women's Economic Empowerment. Washington, DC: International Center for Research on Women, 2018. 
35. Bill \& Melinda Gates Foundation. Women's Economic Empowerment. Equal is Greater. 2019. Bill \& Melinda Gates Foundation. https://www.gatesfoundation.org/equal-is-greater/ (accessed June 25, 2019).

36. The World Bank. World Development Report 2012: Gender Equality and Development. Washington, D.C.: The World Bank, 2011.

37. Supriya, G. The Impact of Lending to Women on Household Vulnerability and Women's Empowerment: Evidence from India. World Dev 36, no. 12, (2008): 2620-42.

38. Austrian, K., E. Soler-hampejsek, Z. Duby, P.C. Hewett. When He Asks for Sex, You Will Never Refuse: Transactional Sex and Adolescent Pregnancy in Zambia. Stud Fam Plann. (2019):1-14.

39. Bongaarts, J., A.K. Blanc, and K.J. McCarthy. The Links Between Women's Employment and Children at Home: Variations in Low- and Middle-Income Countries by World Region. Popul Stud (NY) 73, no. 2 (2019): 149-63. doi:10.1080/00324728.2019.1581896.

40. Finlay, J., and M. Lee. Identifying Causal Effects of Reproductive Health Improvements on Women's Economic Empowerment Through the Population Poverty Research Initiative. Milbank Q 96, no. 2 (2018): 300-22. doi:10.1111/1468-0009.12212.

41. Herrera, C., D. Sahn, and K. Villa. Teen Fertility and Labor Market Segmentation: Evidence from Madagascar. IZA Discuss Pap. no. 10464, 2016.

42. Miller, G. Contraception as Development? New Evidence from Family Planning in Colombia. Econ J 120 (2009): 709-36 doi:10.1111/j.1468-0297.2009.02306.x.

43. Arceo-Gomez, E., R. Campos-Vázquez. Teenage Pregnancy in Mexico: Evolution and Consequences LAJA 51, no. 1, (2013): 109-46. doi:10.2139/ssrn.2198089.

44. McQueston, K., R. Silverman, and A. Glassman. Adolescent Fertility in Low-and Middle-Income Countries: Effects and Solutions: Working Paper 295. Washington, D.C.: Center for Global Development, 2012.

45. Urdinola, P.P., and C. Ospino. Long-Term Consequences of Adolescent Fertility: The Colombian Case. Demogr Res 32, no. 1 (2015): 1487-1518. doi:10.4054/DemRes.2015.32.55.

46. Herrera, C., and D.E. Sahn. The Impact of Early Childbearing on Schooling and Cognitive Skills Among Young Women in Madagascar. Ssrn no. 9362 (2013). doi:10.2139/ssrn.2369482.

47. Bloom, D.E., D. Canning, G. Fink, and J.E. Finlay. Fertility, Female Labor Force Participation, and the Demographic Dividend. J Econ Growth 14, no. 2 (2009): 79-101. doi:10.1007/s10887-009-9039-9.

48. Verick, S. Female Labor Force Participation in Developing Countries. IZA World Labor, no. 87, 2014 doi:10.15185/izawol.87.

49. Kishor, S., and K. Gupta. Women's Empowerment in India and its States: Evidence from the NFHS. Econ Polit Wkly 39, no. 7. (2004): 694-712. DOI: 10.2307/4414645.

50. United Nations Population Division. World Population Prospects 2019. Interactive Data. https:// population.un.org/wpp/DataQuery/. Published 2019. Accessed September 6, 2019.

51. Office of the Registrar General and Census Commissioner India. Adolescent and Youth Population. New Delhi, India; 2015. 
52. Santhya, K.G., R. Acharya, N. Pandey et al. Understanding the Lives of Adolescents and Young Adults (UDAYA) in Bihar, India. New Delhi: Population Council; 2017.

53. Ministry of Health and Family Welfare. Adolescent Health Strategy Handbook: Rashtriya Kishor Swasthya Karyakram. New Delhi, India; 2014.

54. Santhya K.G., S.J. Jejeebhoy. Adolescents and Youth in India: Challenges and Opportunities. In: Jejeebhoy S.J., P.M. Kulkarni, K.G. Santhya, F. Mehrotra, eds. Population and Reproductive Health in India: An Assessment of the Current Situation and Future Needs. New Delhi: Oxford University Press; 2014:175-246.

55. International Institute for Population Sciences (IIPS), ICF. National Family Health Survey (NFHS-4), India, 2015-2016, Bihar. New Delhi, India; 2017. doi:https://dx.doi.org/10.1016/j.bjan.2016.04.007.

56. Girls Not Brides. Child Marriage and Maternal Health. London: Girls Not Brides, 2018.

57. Wodon, Q., C. Male, and A. Nayihouba, et al. Economic Impacts of Child Marriage: Global Synthesis Report. Washington D.C.: The World Bank, 2017. 
Annex 


\begin{tabular}{|c|c|c|c|c|}
\hline \multirow[t]{2}{*}{ Region } & \multirow[t]{2}{*}{ Country } & \multirow[t]{2}{*}{ Survey Year } & \multicolumn{2}{|c|}{ Number of Survey Respondents ages 20-49 } \\
\hline & & & weighted & unweighted \\
\hline \multirow{26}{*}{ Africa } & Angola & 2015 & 10935 & 11016 \\
\hline & Burundi & 2016 & 13410 & 13301 \\
\hline & Chad & 2014 & 13785 & 13830 \\
\hline & Comoros & 2012 & 4014 & 4034 \\
\hline & DRC & 2013 & 14773 & 14846 \\
\hline & Ethiopia & 2016 & 12302 & 12185 \\
\hline & Gabon & 2012 & 6638 & 6588 \\
\hline & Gambia & 2013 & 7826 & 7770 \\
\hline & Ghana & 2014 & 7771 & 7640 \\
\hline & Guinea & 2012 & 7119 & 7148 \\
\hline & Kenya & 2014 & 11908 & 11878 \\
\hline & Lesotho & 2014 & 5181 & 5079 \\
\hline & Liberia & 2013 & 7159 & 7324 \\
\hline & Malawi & 2015 & 19299 & 19289 \\
\hline & Namibia & 2013 & 7270 & 7319 \\
\hline & Niger & 2012 & 9330 & 9259 \\
\hline & Nigeria & 2013 & 31128 & 31043 \\
\hline & Rwanda & 2014 & 10729 & 10718 \\
\hline & Senegal & 2015-16 & 13715 & 13502 \\
\hline & Sierra Leone & 2013 & 12780 & 12607 \\
\hline & South Africa & 2016 & 7087 & 7009 \\
\hline & Tanzania & 2015 & 10362 & 10334 \\
\hline & Togo & 2013 & 7780 & 7747 \\
\hline & Uganda & 2016 & 14242 & 14230 \\
\hline & Zambia & 2013 & 12786 & 12725 \\
\hline & Zimbabwe & 2015 & 7756 & 7799 \\
\hline \multirow{11}{*}{ Asia } & Armenia & 2015 & 5391 & 5373 \\
\hline & Cambodia & 2014 & 14685 & 14572 \\
\hline & India & 2015 & 100062 & 100562 \\
\hline & Indonesia & 2012 & 38680 & 38400 \\
\hline & Kyrgyz Republic & 2012 & 6571 & 6608 \\
\hline & Maldives & 2016 & 6600 & 6684 \\
\hline & Myanmar & 2015 & 11075 & 11050 \\
\hline & Nepal & 2016 & 10264 & 10240 \\
\hline & Philippines & 2017 & 20177 & 19954 \\
\hline & Tajikistan & 2017 & 8807 & 8820 \\
\hline & Timor-Leste & 2016 & 9622 & 9481 \\
\hline \multirow{5}{*}{$\begin{array}{l}\text { Latin America and the } \\
\text { Caribbean }\end{array}$} & Colombia & 2015 & 30192 & 29375 \\
\hline & Dominican Republic & 2012 & 7552 & 7508 \\
\hline & Guatemala & 2014 & 20121 & 20143 \\
\hline & Haiti & 2016 & 11206 & 11064 \\
\hline & Peru & 2012 & 19465 & 19399 \\
\hline Europe & Albania & 2017 & 9286 & 9162 \\
\hline
\end{tabular}




\begin{tabular}{|c|c|c|c|c|c|c|c|}
\hline Region & Country & 20-24 & 25-29 & $30-34$ & $35-39$ & $40-44$ & $45-49$ \\
\hline \multirow{26}{*}{ Africa } & Angola & 58.1 & 71.7 & 77.5 & 82.5 & 85.7 & 87.2 \\
\hline & Burundi & 81.2 & 89.6 & 93.5 & 93.6 & 94.6 & 95.1 \\
\hline & Chad & 45.5 & 51.5 & 59.2 & 58.1 & 61.5 & 63.9 \\
\hline & Comoros & 33.9 & 46.7 & 53.1 & 54.5 & 56.7 & 61.8 \\
\hline & DRC & 67.3 & 81.0 & 83.3 & 84.5 & 86.8 & 87.4 \\
\hline & Ethiopia & 47.3 & 53.5 & 56.1 & 53.9 & 54.9 & 51.9 \\
\hline & Gabon & 35.2 & 52.9 & 63.6 & 73.1 & 78.2 & 78.4 \\
\hline & Gambia & 40.4 & 59.4 & 62.2 & 69.2 & 76.5 & 75.4 \\
\hline & Ghana & 65.6 & 85.2 & 88.6 & 93.1 & 94.5 & 93.3 \\
\hline & Guinea & 67.0 & 77.9 & 84.2 & 88.2 & 90.4 & 87.0 \\
\hline & Kenya & 59.9 & 76.3 & 80.9 & 82.2 & 87.6 & 85.2 \\
\hline & Lesotho & 39.5 & 53.6 & 66.0 & 63.1 & 62.9 & 56.4 \\
\hline & Liberia & 47.2 & 61.0 & 67.3 & 74.4 & 78.2 & 77.4 \\
\hline & Malawi & 64.2 & 72.1 & 76.6 & 79.8 & 79.7 & 78.1 \\
\hline & Namibia & 36.5 & 57.3 & 63.6 & 60.8 & 64.0 & 59.2 \\
\hline & Niger & 19.0 & 26.4 & 34.1 & 39.3 & 40.8 & 43.1 \\
\hline & Nigeria & 52.2 & 67.7 & 77.8 & 82.2 & 83.6 & 84.4 \\
\hline & Rwanda & 82.5 & 92.6 & 94.6 & 95.8 & 95.8 & 95.5 \\
\hline & Senegal & 41.3 & 55.8 & 64.3 & 70.9 & 73.6 & 76.2 \\
\hline & Sierra Leone & 67.2 & 80.9 & 87.9 & 88.1 & 87.2 & 90.6 \\
\hline & South Africa & 24.5 & 43.1 & 50.8 & 52.5 & 54.6 & 57.6 \\
\hline & Tanzania & 75.1 & 83.3 & 88.0 & 90.4 & 91.3 & 90.3 \\
\hline & Togo & 62.5 & 81.7 & 87.0 & 90.9 & 91.0 & 93.1 \\
\hline & Uganda & 77.3 & 84.2 & 86.4 & 87.9 & 88.2 & 91.3 \\
\hline & Zambia & 43.2 & 58.5 & 64.8 & 67.8 & 73.3 & 72.3 \\
\hline & Zimbabwe & 47.0 & 60.2 & 62.2 & 64.1 & 64.5 & 66.9 \\
\hline \multirow{11}{*}{ Asia } & Armenia & 24.1 & 41.1 & 41.0 & 53.4 & 59.8 & 59.3 \\
\hline & Cambodia & 77.1 & 80.6 & 83.5 & 86.8 & 88.1 & 85.2 \\
\hline & India & 21.3 & 28.9 & 35.1 & 40.1 & 40.4 & 37.8 \\
\hline & Indonesia & 58.6 & 61.8 & 63.6 & 66.9 & 72.4 & 72.8 \\
\hline & Kyrgyz Republic & 24.9 & 37.2 & 36.2 & 40.5 & 46.5 & 43.5 \\
\hline & Maldives & 58.8 & 52.6 & 46.6 & 44.4 & 46.6 & 52.9 \\
\hline & Myanmar & 72.5 & 73.5 & 76.1 & 76.9 & 75.6 & 74.4 \\
\hline & Nepal & 62.1 & 66.9 & 73.7 & 74.6 & 76.2 & 74.8 \\
\hline & Philippines & 53.9 & 58.0 & 60.3 & 68.4 & 71.9 & 69.8 \\
\hline & Tajikistan & 16.4 & 23.6 & 30.3 & 36.1 & 37.4 & 41.4 \\
\hline & Timor-Leste & 28.7 & 38.8 & 45.3 & 51.2 & 51.3 & 53.1 \\
\hline \multirow{5}{*}{$\begin{array}{l}\text { Latin America and the } \\
\text { Caribbean }\end{array}$} & Colombia & 72.4 & 79.9 & 80.6 & 81.7 & 78.7 & 75.2 \\
\hline & Dominican Republic & 54.9 & 64.0 & 70.9 & 71.6 & 69.6 & 65.4 \\
\hline & Guatemala & 47.8 & 52.8 & 54.9 & 55.9 & 56.6 & 56.9 \\
\hline & Haiti & 41.6 & 66.2 & 75.2 & 81.1 & 85.4 & 83.6 \\
\hline & Peru & 73.9 & 77.1 & 77.0 & 80.6 & 82.4 & 83.3 \\
\hline Europe & Albania & 37.1 & 44.6 & 49.9 & 50.0 & 52.5 & 51.3 \\
\hline
\end{tabular}




\begin{tabular}{|c|c|c|}
\hline Region & Country & Women married/cohabitating \\
\hline \multirow{26}{*}{ Africa } & Niger & 94 \\
\hline & Chad & 85 \\
\hline & Guinea & 85 \\
\hline & Nigeria & 82 \\
\hline & Sierra Leone & 80 \\
\hline & Gambia & 79 \\
\hline & Ethiopia & 78 \\
\hline & Senegal & 78 \\
\hline & Togo & 78 \\
\hline & Malawi & 77 \\
\hline & DRC & 76 \\
\hline & Comoros & 76 \\
\hline & Zimbabwe & 74 \\
\hline & Uganda & 73 \\
\hline & Tanzania & 73 \\
\hline & Zambia & 72 \\
\hline & Burundi & 71 \\
\hline & Liberia & 71 \\
\hline & Kenya & 71 \\
\hline & Ghana & 67 \\
\hline & Angola & 67 \\
\hline & Lesotho & 65 \\
\hline & Rwanda & 64 \\
\hline & Gabon & 64 \\
\hline & South Africa & 42 \\
\hline & Namibia & 42 \\
\hline \multirow{11}{*}{ Asia } & Nepal & 89 \\
\hline & India & 85 \\
\hline & Tajikistan & 85 \\
\hline & Indonesia & 84 \\
\hline & Maldives & 79 \\
\hline & Cambodia & 78 \\
\hline & Kyrgyz Republic & 78 \\
\hline & Timor-Leste & 77 \\
\hline & Philippines & 72 \\
\hline & Armenia & 72 \\
\hline & Myanmar & 68 \\
\hline \multirow{5}{*}{ Latin America and the Caribbean } & Guatemala & 69 \\
\hline & Peru & 67 \\
\hline & Haiti & 64 \\
\hline & Dominican Republic & 62 \\
\hline & Colombia & 61 \\
\hline Europe & Albania & 79 \\
\hline
\end{tabular}


